\title{
Nitrenium Ion Azaspirocyclization-Spirodienone Cleavage: A New Synthetic Strategy for the Stereocontrolled Preparation of Highly Substituted Lactams and $\mathrm{N}$-Hydroxy Lactams
}

\author{
Duncan J. Wardrop* and Matthew S. Burge \\ Department of Chemistry, University of Illinois at Chicago 845 West Taylor Street, Chicago, IL \\ 60607.
}

\section{Abstract}

Although 1,4-cyclohexadienes $\mathbf{2}$, obtained through the Birch reduction of arenes $\mathbf{1}$, have found widespread use as masked $\beta$-oxo carbonyl synthons $\mathbf{3}$, the possibility that 2,5-cyclohexadienones $\mathbf{5}$ might also be employed to the same end has been overlooked despite their ready availability. As part of our ongoing investigation of the synthetic chemistry of nitrenium ions, we have developed a novel and efficient strategy for the stereoselective preparation of di- and trisubstituted azetidinone, pyrrolidinone and piperidinone derivatives, which features the ozonolytic cleavage of azaspirocyclic 2,5-cyclohexadienones 12. For example, ozonolysis of spirodienone $12 \mathrm{c}$ in $\mathrm{CH}_{2} \mathrm{Cl}_{2}$ and reductive workup with dimethyl sulfide generated unstable $\beta$-formyl ester $\mathbf{2 1}$ whereas cleavage in $\mathrm{MeOH}$ followed by reduction with thiourea led to hemiacetal $\mathbf{2 2}$. While both $\mathbf{2 1}$ and 22 partially decompose upon exposure to silica gel, they can be trapped in situ, with a variety of weakly basic nucleophiles, to usefully substituted products. The requisite spirodienone substrates are readily accessible through the nitrenium ion cyclization of alkyl $\omega$-arylhydroxamates $\mathbf{1 0}$, proceeds with moderate to high diastereoselectivity.

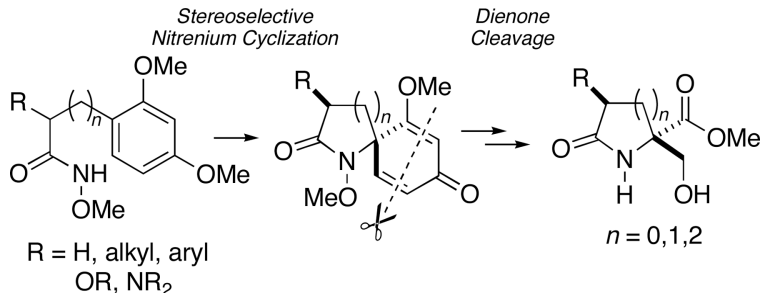

\section{Keywords}

nitrenium ions; dearomatization; ozonolysis; 1,3-dicarbonyl synthon; $N$-heterocycles; hypervalent iodine; alkyl hydroxamates; $N$-hydroxy lactams; hydroxamic acid; azetidinones; pyrrolidinones and piperidinones

\section{Introduction}

The synthetic equivalency of benzenoid systems and carbonyl-based functional groups ${ }^{1}$ has been widely exploited since Woodward's biosynthetically inspired use of a veratryl group as a masked hexa-2,4-dienedioic acid during his total synthesis of strychnine. ${ }^{2}$ Among the

*To whom correspondence should be addressed. Tel: 312-996-8542. Fax: 312-996-0431.

Supporting Information Available. Experimental procedures and characterization data for all new compounds. This material is free of charge via the Internet at http://pubs.acs.org. 
numerous reports concerning the oxidative cleavage of aromatic and heteroaromatic rings to form carboxylic acids, lactones and other related functionality, ${ }^{3}$ the use of disubstituted arenes $\mathbf{1}$ as latent 1,3-dicarbonyl groups $\mathbf{3}$ has proven to be particularly fruitful (Scheme 1). Rather than involving a direct oxidation, in this case, Birch reduction of $\mathbf{1}$ and cleavage of one or both double bonds in the resulting dihydroaromatic compound 2 , most commonly through ozonolysis, serves to unmask the latent dicarbonyl system. ${ }^{4}$ This two-step protocol is tolerant of a wide range of aryl substituents $\left(\mathrm{R}^{1}, \mathrm{R}^{2}\right)$ and has successfully been applied to the synthesis of $\beta$-keto esters, ${ }^{5} \omega$-formyl esters, ${ }^{6}$ malonate esters, ${ }^{7} \beta$-diketones,${ }^{8} \beta$-formyl ketones, ${ }^{9}$ and even higher order polyketides. ${ }^{10}$

In contrast to cyclohexadienes $\mathbf{2}$, there are only a handful of accounts documenting the ozonolytic cleavage of 2,5-cyclohexadienones $\mathbf{5}$, their electron deficient congeners, to form 1,3-dicarbonyl compounds 7 (Scheme 2). ${ }^{11}$ Given the complex nature of the reaction between dienones and ozone, the absence of reports concerning this transformation is perhaps understandable. The ozonolysis of cross-conjugated ketones was first studied by Harries, who noted that while treatment of phorone with excess ozone formed mesoxaldialdehyde (6) and acetone, ${ }^{12}$ exposure of this substrate to one equivalent of ozone, resulted in anomalous ozonolysis ${ }^{13}$ to produce $\beta, \beta$-dimethyl acrylic acid.

More recently, Caspi ${ }^{11 \mathrm{a}-\mathrm{c}}$ and Rodig ${ }^{11 \mathrm{~d}}$ have independently investigated the ozonolysis of steroidal $\Delta^{1,4}-3$-ketones and found the outcome of this reaction to be similarly complex. Ozonolysis of 1-dehydrotestosterone acetate $(\mathbf{8})$ in ethyl acetate, ${ }^{11 \mathrm{c}}$ for example, provided keto aldehyde 9 in low yield together with nine other products, which were proposed to arise through anomalous ozonolysis of $\mathbf{8}$, Baeyer-Villiger oxidation of aldehyde $9,{ }^{14}$ and the partial ozonolytic cleavage of the dienone ring. ${ }^{15}$

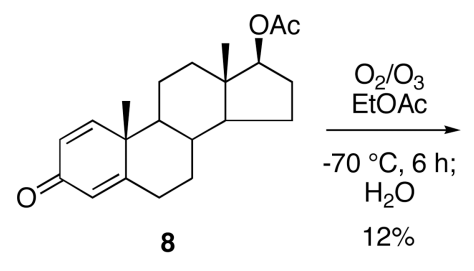

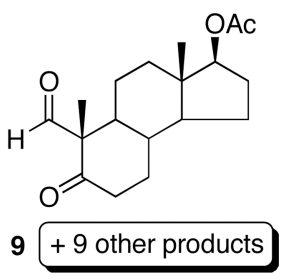

Notwithstanding these unpromising observations, successful ozonolytic cleavage of systems such as $\mathbf{5}$ remains synthetically appealing for a number of reasons, not least of which is the prospect that a route to 1,3-dicarbonyl systems, which bear an asymmetric quaternary stereocenter at C-2 might be established through the ozonolysis of differentially 4,4disubstituted 2,5-cyclohexadienones $\mathbf{5} .{ }^{16}$ That the requisite dienones precursors $\mathbf{5}$ are readily available, through with the oxidation of phenols $\mathbf{4}$ and other electron-rich arenes, ${ }^{17}$ is an additionally attractive feature of this type of transformation.

Our interest in the ozonolytic cleavage of 2,5-cyclohexadienones was spurred by this laboratory's ongoing study of the synthetic application of acyl nitrenium ions. ${ }^{18,19,20} \mathrm{We}$ have recently reported a stereoselective nitrenium ion spirocyclization involving the treatment of $\alpha$ - and $\beta$-substituted methyl 3-(methoxyphenyl)propiohydroxamates $\mathbf{1 0}(n=1)$ with phenyliodine(III) bis(trifluoroacetate) (PIFA) to provide spirolactams 12 with useful levels of diastereoselectivity (Scheme 3). ${ }^{21}$

Given the ease with which spirocycles $\mathbf{1 2}$ can be accessed and our ability to control the configuration of the spirocyclic center, we were prompted to consider the possibility that ozonolytic cleavage of the dienone ring would offer convenient access to lactams 13 that 
possess a nitrogen-bearing quaternary stereogenic center. Since spiroazetidinone, pyrrolidinone and piperidinone systems $\mathbf{1 2}(n=0,1,2)$ are all accessible through the oxidative cyclization of alkyl hydroxamates $\mathbf{1 0},{ }^{19 \mathrm{~b}}$ and given the fact that this reaction is tolerant of a wide range of aryl and sidechain substituents, this strategy potentially offers a route to a diverse array of target molecules. Among the heterocyclic systems that might potentially be accessed through application of the two-step sequence outlined in Scheme 3, the targets shown in Figure 1 are of particular interest.

The marine natural product (-)-dysibetaine (14) is a neuroexcitotoxin, which is believed to bind to the glutamate receptors present in the central nervous system of mice, ${ }^{22,23}$ while kaitocephalin (15), an AMPA/NMDA antagonist isolated from the fungus Eupenicillium shearii PF1191, protects hippocampal neurons from kainate toxicity. ${ }^{24}$ Salinosporamide (17) and lactacystin (18), on the other hand, are both inhibitors of the proteasome, while the latter is additionally a potent cytotoxic agent. ${ }^{25}$ That the dienone cleavage strategy might also lend itself to the development of an expedient synthetic route to 4,4-disubstituted $\beta$ lactams $(\mathbf{1 3}, n=0)$ is also appealing in view of the pharmacological importance of these systems. Tigemonam (19), for example, is a potent oral antibiotic that is resistant to $\beta$ lactamase-mediated hydrolysis. ${ }^{26}$

Having recently reported the application of the reaction sequence shown in Scheme 3 to the total synthesis of (-)-dysibetaine, ${ }^{27}$ in this paper, we now disclose a full account of our development of two complementary strategies for the ozonolytic cleavage of spirolactams 2,5-cyclohexadienones 12 and the implementation of this transformation, together with the stereoselective nitrenium ion spirocyclization reaction, as a valuable strategy for the synthesis of di- and trisubstituted lactams and $N$-hydroxy lactams.

\section{Results and Discussion}

\section{Substrate Preparation}

Given Caspie and Rodig's observations concerning the cleavage of steroidal systems, our initial choice of spirodienone substrate was guided by the recognition that in order to promote efficient ozonolysis, it would be necessary to address the inherent electrondeficiency of these cross-conjugated ketones. Since it is well known that electron-releasing substituents increase the reactivity of alkenes towards ozone, ${ }^{28,29}$ we opted to examine the cleavage of dienone substrates activated by the presence of a $\beta$-methoxy substituent. Our investigation therefore commenced with the preparation of a series of dienones 12, which where accessed through the oxidative spirocyclization of alkyl hydroxamates $\mathbf{1 0},{ }^{30}$ under conditions previously developed in this laboratory (Table 1). ${ }^{21}$ Thus, upon treatment of a solution of 10 in $\mathrm{CH}_{2} \mathrm{Cl}_{2}$ at $-78{ }^{\circ} \mathrm{C}$ with 1.2 equivalents of phenyliodine(III) bis(trifluoroacetate) (PIFA) in methanol followed by warming to $-15^{\circ} \mathrm{C}$, spirocyclization took place smoothly to afford the desired azaspirans $\mathbf{1 2}$ in good to excellent yield..$^{31}$

As anticipated from our investigation of the stereochemistry of this reaction, ${ }^{21}$ substrates $10 \mathbf{g}-\mathbf{m}$ underwent spirocyclization to provide the anti spirolactam diastereomers with reasonable selectivity. Figure 2 shows a possible rationale for this general observation. We believe that spirocyclization of the nitrenium ion generated from $\mathbf{1 0}$ preferentially proceeds via conformer $\mathbf{B}$ to form anti-12. Conformer $\mathbf{A}$, on the other hand, is destabilized due to nonbonding interactions (benzylic strain) ${ }^{32}$ between the substituents on the side-chain and the ortho position of the aromatic ring. ${ }^{33}$

After separation by chromatography and/or crystallization, the relative stereochemistry of the individual diastereomers was readily assigned on the basis of correlations observed in the 2D-NOESY spectra. In the case of products $12 \mathbf{i}$ and $\mathbf{1 2 k}$, separation of the individual 
spirodienone diastereomers was not possible and consequently the mixtures were used in the subsequent step.

The successful cyclization of benzyl hydroxamates ${ }^{34} \mathbf{1 0 b}, \mathbf{1 0 d}$ and $10 \mathrm{f}$ is noteworthy from a synthetic standpoint since it adds additional flexibility to our methodology: in these cases, hydrogenolysis of the benzyl ether, after dienone cleavage, provides access to $N$-hydroxy lactams, which are important bioactive targets (vide infra). ${ }^{35}$

\section{Exploratory Dienone Ozonolysis Studies}

Proceeding now to examine cleavage of the dienone system, we chose spiropyrrolidinone 12c for the purposes of this exploratory study (Scheme 4).

Exposure of a solution of $12 \mathrm{c}$ in $\mathrm{CH}_{2} \mathrm{Cl}_{2}(0.12 \mathrm{M})$ at $-78^{\circ} \mathrm{C}$ to a stream of ozonated oxygen for $30 \mathrm{~min}$ resulted in complete consumption of starting material and the formation of a less polar product, as indicated by thin-layer chromatography. Subsequent reduction of this ozonide intermediate with dimethyl sulfide (10 equiv) at room temperature for $12 \mathrm{~h}$ gave, upon concentration of the reaction mixture, $\beta$-formyl ester 21 . While the spectroscopic data $\left({ }^{1} \mathrm{H}\right.$ NMR, ${ }^{13} \mathrm{C}$ NMR, IR, and MS) from this compound were fully consistent with the structure assigned, purification of $\mathbf{2 1}$ by flash chromatography resulted in partial decomposition, and the product was isolated in moderate yield. The instability of $\mathbf{2 1}$ was further apparent from its rapid decomposition, upon standing at room temperature, to form an intractable mixture of products. That the sterically congested aldehyde group in this compound is highly reactive is also evident from its spontaneous reaction with methanol to generate adduct 22. Ozonolysis of $\mathbf{1 2 c}$ in methanol, followed by reduction of the putative $\alpha$ methoxy hydroperoxide intermediate ${ }^{36}$ with thiourea (1.25 equiv), ${ }^{37}$ proceeded cleanly to yield hemiacetal 22 as a 1:1 mixture of epimers. While this reaction was highly efficient, as evidenced by NMR analysis of the crude product mixture, attempts to purify 22 by flash chromatography resulted in loss of methanol and formation of aldehyde 21, which was also isolated in diminished yield (60\%). Fortunately in this case, there was no need for purification since filtration of the reaction mixture through a plug of celite after ozonolysis served to remove the precipitated thiourea $S$-dioxide and provided material of sufficient purity to be utilized in subsequent manipulations. In view of the instability of both aldehyde 21 and hemiacetal 22, we now examined the possibility that these compounds might be intercepted in situ, either through reduction or reaction with nucleophiles in general, to provide more tractable products (Scheme 5).

Encouragingly, ozonolysis of 12c in methanol, reduction with thiourea and then treatment of the reaction mixture with hydroxylamine hydrochloride (2.4 equiv) and sodium acetate (1.8 equiv) provided stable aldoxime $\mathbf{2 3}$ in good yield (75\%). Likewise, hemiacetal $\mathbf{2 2}$ also underwent condensation with 2,4-dinitrophenylhydrazine to form hydrazone 24, albeit under somewhat more forcing conditions. Although attempts to prepare 4,4-dimethyldioxane acetal $\mathbf{2 5}$ under a variety of dehydrating conditions were unsuccessful, treatment of $\mathbf{2 2}$ with 1,2-ethanedithiol in the presence of concentrated hydrochloric acid did provide 1,2dithiolane 26 albeit in modest yield (47\%). Homologation of 22, on the other hand, proved to be more successful. Horner-Wittig reaction of 22 with (carboethoxymethylene)triphenylphosphorane (2.2 equiv) proceeded efficiently to provide enoate $\mathbf{2 7}$ as a single geometrical isomer. ${ }^{38}$ In this case, the ozonolysis reaction mixture was concentrated to remove methanol and the carboethoxymethylenation then carried out in toluene. Interestingly, $\mathbf{2 2}$ did not undergo methylenation with the ylide generated from methyl triphenylphosphonium bromide and $n$-butyllithium. In fact, treatment of either $\mathbf{2 1}$ or 22 with strongly basic nucleophiles, including Grignard and organozinc reagents, failed to provide the expected addition products. This general observation may be due to decomposition of these substrates through retro-aldol or retro-Claisen processes, which 
could occur upon deprotonation of the hydroxyl group, in the case of 22, or upon nucleophilic addition to the aldehyde group in $\mathbf{2 1} .{ }^{39}$

We next turned our attention to the reduction of the initial ozonolysis products and in particular to the transformation of these compounds to $\beta$-hydroxy ester 30c via selective reduction of the aldehyde and hemiacetal groups. While attempts to generate 30c through insitu reduction of $\mathbf{2 1}$ with sodium borohydride gave unsatisfactory results, concentration of the ozonolysis reaction mixture and reduction with $\mathrm{LiBH}_{4}$ in THF provided the corresponding bis(hydroxymethyl)pyrrolidinone, ${ }^{40}$ which because of its polarity, was converted to bis- $O$-acetate 29 prior to purification. Treatment of hemiacetal 22 with $\mathrm{NaBH}_{4}$ or $\mathrm{LiBH}_{4}$, on the other hand, failed to provide any useful results. Reasoning that a weaker reducing agent might prove selective for the hemiacetal group, without affecting the methyl ester or promoting decomposition, sodium triacetoxyborohydride in acetic acid was evaluated. ${ }^{41}$ Thus, after ozonolysis of $\mathbf{1 2 c}$ and reductive workup with thiourea, the reaction mixture was concentrated under reduced pressure then treated with $\mathrm{NaBH}(\mathrm{OAc})_{3}$ (4 equiv) in acetic acid. Reduction of latent aldehyde $\mathbf{2 2}$ proceeded smoothly at room temperature and was complete within $24 \mathrm{~h}$. Treatment of the reaction mixture with aqueous $\mathrm{HCl}$ for $20 \mathrm{~min}$, extractive workup and purification by flash chromatography then provided $\beta$-hydroxy ester 30c in $81 \%$ overall yield from $\mathbf{1 2 c}$ (Table 2, entry 3 ).

\section{Establishing the Scope and Limitations of Dienone Cleavage}

Having successfully established the practical viability of dienone cleavage and in-situ derivatization, we now proceeded to extend our study to include the remaining dienone substrates $\mathbf{1 2}$ in order to evaluate the scope and limitations of this chemistry. In view of the synthetic value of $\beta$-hydroxy esters of general structure 30 , as both masked 2-

hydroxymethyl amino acids ${ }^{42}$ and potential building blocks for the preparation of the natural products dysibetaine (14) and lactacystin (18), we opted to focus our attention on in-situ reduction of the ozonolysis products with sodium triacetoxyborohydride. The results of this study are detailed in Table 2 .

Encouragingly, the reactivity of spiropyrrolidinone $12 \mathrm{c}$ towards ozone appeared to be general: cleavage of the homologous azaspiro[3.5]nonadienone (entries $1 \& 2$ ) and azaspiro[5.5] undecadienone (entries $5 \& 6$ ) systems proceeded to furnish the respective disubstituted azetidinone and piperidinone products 30. The successful ozonolysis spiroazetidinones 12a and 12b is of particular note since this transformation provides expedient access to usefully functionalized 4,4-disubstituted $\beta$-lactams. ${ }^{43}$ The disparity in yield observed during the formation of 30a and 30b appears to result from the greater polarity of the former product, which hampers its purification by flash chromatography. While the beneficial effect of $O$-benzyl groups, upon the efficiency of dienone cleavage, was also apparent during the ozonolysis of spiropyrrolidinones $\mathbf{1 2 c}$ and 12d, this effect did not extend to compounds $\mathbf{1 2 e}$ and $\mathbf{1 2 f}$.

A remarkable structure-reactivity relationship emerged during the cleavage of substrates 12a-e. While the reaction of spiroazetidinones $12 \mathbf{a}$ and $\mathbf{1 2 b}$ with ozone was complete within 30 minutes, ozonolysis of the corresponding pyrrolidinones $\mathbf{1 2 c}$ and $\mathbf{1 2 d}$ was significantly slower, requiring $1 \mathrm{~h}$. Even more strikingly, piperidinones $\mathbf{1 2 e}$ and $\mathbf{1 2 f}$ reacted very sluggishly with cleavage not reaching completion even after exposure to ozone for $3 \mathrm{~h}$. Purification of the product mixtures, in the case of this latter pair of substrates, also proved to be problematic due to the presence of several, minor by-products. Fortunately, acetylation of the reaction mixtures, using $\mathrm{Ac}_{2} \mathrm{O}$ in pyridine, provided the corresponding $O$-acetate derivatives, which where more amenable to purification by flash chromatography. Rather unexpectedly, spiropiperidinone $12 \mathrm{n}$ proved to be considerably more reactive towards ozone than either 12e or 12f and underwent rapid ozonolysis to provide 30n in excellent yield, 
after in-situ reduction. The successful cleavage of $\mathbf{1 2 n}$ is notable since it opens a possible route to quaternary tetrahydroisoquinoline-3-carboxylic acid (Tic) derivatives, ${ }^{44}$ which are of interest as conformationally restricted amino acids. A more detailed discussion of the possible origins of this structure-reactivity pattern is presented in Section 5.

Having established the viability of cleavage in unsubstituted 4, 5 and 6-membered spirolactams, attention now turned to the $\alpha$ and $\beta$-substituted spiropyrrolidinones $\mathbf{3 0 g}-\mathbf{l}$. We were encouraged to find, in fact, that the presence of $\alpha$-substituents in the pyrrolidinone ring was tolerated with cleavage giving the corresponding 2,4-disubstituted pyroglutamate derivatives with moderate to excellent efficiency. That attempts to ozonize $\mathbf{1 2} \mathbf{m}$, the isomer

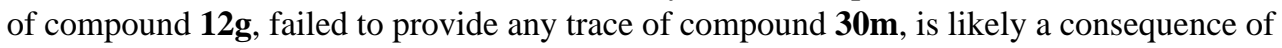
the increased steric encumbrance imposed upon the dienone ring by the $\beta$-methyl substituent in this substrate.

\section{An Alternative Strategy for Dienone Cleavage}

The extended reaction times and modest yields encountered during the ozonolysis of substrates 12e and 12f, coupled with the failure of $\beta$-substituted spiropyrrolidinone $12 \mathbf{m}$ to undergo cleavage prompted a search for an alternative, more efficient strategy for cleavage of the dienone ring system. Given the greater reactivity of 1,4-cyclohexadienes towards ozone as compared to their electron-deficient congeners, the logical course of action at this stage seemed to be to reduce the dienone carbonyl group and subject the resulting dienylic alcohol(s) 31 to ozonolysis (Scheme 6).

Although the 1,2-reduction of 2,5-cyclohexadienones is well documented, ${ }^{45}$ a potential caveat with this plan was the propensity of the reduction products $\mathbf{3 1}$ to potentially undergo rearrangement during purification. ${ }^{46}$ Fortunately, reduction of dienone 12c, under Luche conditions $\left(\mathrm{NaBH}_{4}, \mathrm{CeCl}_{3}, \mathrm{MeOH}\right)^{47}$ proceeded rapidly at $0{ }^{\circ} \mathrm{C}$ to give a mixture of diastereomers 31, which could be isolated with excellent mass recovery. As these alcohols proved to be highly acid sensitive and decomposed upon exposure to silica gel, they were immediately submitted to ozonolysis without further purification (Table 2).

Gratifyingly, ozonolysis of diene 31 in $\mathrm{CH}_{2} \mathrm{Cl}_{2}$ at $-78{ }^{\circ} \mathrm{C}$ occurred rapidly, with the starting material being consumed within $30 \mathrm{~min}$ as opposed to $1 \mathrm{~h}$ for dienone 12c. Sequential reduction of the peroxidic intermediates with thiourea (1.25 equiv) and sodium triacetoxyborohydride (5 equiv) in acetic acid then proceeded without incident to furnish $\beta$ hydroxy ester 30c in good yield. While this two-step protocol was slightly less efficient than direct dienone ozonolysis in this case (76 vs. 81\%), its application to the remaining substrates in Table 2 proved to be considerably more rewarding. With the exception of 12a, 12b and 12n, improvements in yield and a decrease in reaction time were observed in all cases. Indeed, ozonolysis of the intermediate dienylic alcohols was complete within $30 \mathrm{~min}$ for all substrates, including spiropiperidinones 12e and 12f. The transformation of hindered $\mathbf{1 2} \mathbf{m}$ to compound $\mathbf{3 0 m},{ }^{48}$ albeit in low yield, under these conditions is also of note, since this product could not be prepared through direct ozonolysis of the dienone system. In the case of compounds 12a and 12n, complex mixtures of products where obtained, which we believe arise from decomposition of the intermediate dienylic alcohols prior to ozonolysis.

\section{Assessment of Spirodienone Structure-Reactivity Relationships}

Steric effects are known to play a significant role in determining the rate of 1,3-dipolar cycloaddition between ozone and unsaturated systems, including alkenes and arenes. ${ }^{49} \mathrm{We}$ have rationalized the marked variation in reactivity towards ozone displayed by spirodienones 12 in terms of steric hindrance above $(\beta)$ and below $(\alpha)$ the plane of the 
dienone ring system, which varies as a function of the size of the adjoining lactam ring (Table 3).

Notwithstanding possible dipole and stereoelectronic effects, ${ }^{50}$ we believe that ozone approaches the spirocyclic cyclohexadienones from the $\alpha$ face, anti to the $N$-methoxyl group, which in all substrates bisects the dienone ring and thereby disfavors $\beta$ attack. Our assumption that the $\mathrm{N}-\mathrm{OMe}$ group is more sterically demanding than the methylene group appears to be born out by the observation that substrate $\mathbf{1 2 m}$, which possesses a methyl substituent at the $\beta$ position of the pyrrolidinone ring, is quite inert to ozone. Molecular mechanics minimization (MMMF) of the geometries of dienones 12a, 12c, 12e and 12n using the SPARTAN computational interface ${ }^{51}$ reveals that methylene group attached to the spirocenter progressively shields the $\beta$ face of the adjoining dienone ring from ozone cycloaddition as the lactam ring increases in size. The increasing steric influence played by the methylene group in going from azetidinone to piperidinone is apparent from the decrease in the angle $(\phi)$ formed between the methylene group, spirocenter and the carbonyl carbon of the dienone ring. That the dienone rings in spiroazetidinones 12a and $\mathbf{1 2 b}$ are more accessible to attack is also evident from the fact only these substrates undergo conjugate addition of methanol during azaspirocyclization. While the dramatic increase in reactivity of dienylic alcohols 31, as compared to their corresponding dienone partners can be rationalized in terms of the attenuation of the electron-withdrawing properties of the carbonyl group, it is not immediately apparent why this should result in loss of the structure reactivity relationship.

\section{Reductive Cleavage of $\mathbf{N}$-Methoxy and $\mathbf{N}$-Benzyloxy Lactams}

In order to confirm the practical utility of the nitrenium ion cyclization-dienone cleavage strategy, it was necessary now to address the issue of $\mathrm{N}-\mathrm{O}$ bond scission in the cleavage products 30. Although the reduction of hydroxylamines, hydroxamic acids, and $N$-hydroxy lactams can readily be accomplished with a variety of reagents, metal ion-mediated reduction of $N$-alkoxy lactams is often more demanding since these systems lack an acidic chelation site. ${ }^{52}$ While this transformation has been accomplished with a number of reagents, including: hydrogenolysis over heterogeneous catalysts ${ }^{53}$ or reduction with Raney nickel $;{ }^{54} \mathrm{SmI}_{2} ;{ }^{55}$ sodium ${ }^{56}$ and aluminum amalgam $;{ }^{57}$ LDA $;{ }^{58}$ tert-butyldimethylsilyl triflate, ${ }^{59} \mathrm{Li} / 4,4^{\prime}$-di-tert-butylbiphenyl $;{ }^{60}$ and Birch reduction, ${ }^{61}$ few are entirely general. From previous studies, we have found the most dependable reducing agent for our relatively hindered substrates to be molybdenum hexacarbonyl. ${ }^{62}$

Reductive cleavage of $\mathbf{3 0}$ proceeds most efficiently when the substrate is heated with 1.2 equivalents of $\mathrm{Mo}(\mathrm{CO})_{6}$ in a degassed mixture of acetonitrile and water $(15: 1)$ for $24 \mathrm{~h}$ and the reaction then exposed to air at room temperature for an equivalent period of time (Table 4). Concentration of the black reaction mixture and purification of the residue by flash chromatography then provides the desired lactams 32 in good yield. Exposure of the reaction mixture to air greatly facilitates purification and failure to carry out this step often results in the contamination of the lactam products with unidentified, non-polar molybdenum complexes. As documented in Table 4, reductive cleavage of the $N$-methoxy lactams proceeded without incident to provide the corresponding pyroglutamate derivatives in good to excellent yield. The successful reduction of $N$-methoxy-2-azetidinone 30a under these mild conditions is notable since direct cleavage of this class of substrate has previously only been accomplished under more stringent conditions involving alkali metals in ammonia. ${ }^{61}$

$\mathrm{N}$-Hydroxy lactams are important synthetic targets, imbued with a wide range of biological activities, for which there are relatively few methods of preparation available. ${ }^{63}$ In this regard, the successful cyclization of the benzyl hydroxamate substrates $\mathbf{1 2 b}, \mathbf{1 2 d}$ and $\mathbf{1 2 f}$ 
and the subsequent compatibility of the $O$-benzyl groups with the dienone cleavage protocol now provided an opportunity to access these target molecules, through selective hydrogenolysis of the benzyl ether in $N$-benzyloxy lactams 30 (Table 5).

Hydrogenation of $\mathbf{3 0 b}, 30 \mathbf{d}$ and $30 \mathrm{f}$ in ethyl acetate proceeded smoothly at atmospheric pressure, in the presence of $10 \% \mathrm{Pd}-\mathrm{C}$, to provide the desired $N$-hydroxy lactams 34 in excellent yield. In all cases, the reaction stopped after debenzylation and no trace of the lactam products, resulting from $\mathrm{N}-\mathrm{O}$ bond cleavage, ${ }^{64}$ could be detected.

\section{Conclusions}

In conclusion, we have reported a novel and efficient strategy for the stereoselective preparation of di- and trisubstituted azetidinone, pyrrolidinone and piperidinone derivatives, which features the ozonolytic cleavage of azaspirocyclic 2,5-cyclohexadienones. Notable features of this methodology include a) the rapidity with which structural complexity is established; b) flexibility $(4,5$, and 6-membered lactams and $N$-hydroxy lactams can be accessed) and; c) the accessibility of the spirodienone substrates, which can be prepared through the nitrenium ion cyclization of alkyl $\omega$-arylhydroxamates with excellent efficiency and moderate to high diastereoselectivity. The results presented herein demonstrate, for the first time, that the ozonolytic cleavage of 2,5-cyclohexadienones is a synthetically viable and potentially powerful method. Since, in addition to the cyclization of nitrenium ions, spirocyclic 2,5-cyclohexadienones, including lactones, lactams and oxazolines, are readily accessible, through the oxidative spirocyclization of phenol derivatives, we anticipate that the chemistry reported herein may offer a general route to $\alpha, \alpha$-disubstituted heterocycles. Future directions for this work will include application of the current method to the synthesis of the natural products lactacystin and kaitocephalin as well as an examination of dienone cleavage in the context of other types of spirodienone.

\section{Experimental Section}

\section{Reagents}

Flash column chromatography was performed according to the method of Still ${ }^{65}$ using silica gel 60 (mesh 230-400). Phenyliodine(III) bis(trifluoroacetate) (PIFA) was prepared according to the procedure reported by Loudon. ${ }^{66}$ Solutions of sodium triacetoxyborohydride were prepared freshly by reacting sodium borohydride with acetic acid.

\section{General Procedure A (Preparation of Spirodienones 12 in $\left.\mathrm{CH}_{2} \mathrm{Cl}_{2}\right) \cdot( \pm)-1,5-M e t h o x y-1-$ azaspiro[3.5]nona-5,8-diene-2,7-dione (12a) (Entry 2, Table 1)}

To a stirred suspension of phenyliodine(III) bis(trifluoroacetate) (PIFA) (580 mg, 1.35 mmol, 1.2 equiv) in $\mathrm{CH}_{2} \mathrm{Cl}_{2}(1 \mathrm{~mL})$, under an atmosphere of $\mathrm{N}_{2}$ at $-78{ }^{\circ} \mathrm{C}$, was added a cold $\left(-78{ }^{\circ} \mathrm{C}\right)$ solution of alkyl hydroxamate $10 \mathrm{a}(253 \mathrm{mg}, 1.12 \mathrm{mmol})$ in $\mathrm{CH}_{2} \mathrm{Cl}_{2}(5 \mathrm{~mL})$ via cannula. The reaction mixture was then allowed to warm to $-15^{\circ} \mathrm{C}$ (bath temperature) over $1.5 \mathrm{~h}$ whereupon $\mathrm{H}_{2} \mathrm{O}(3 \mathrm{~mL})$ was added and the cooling bath removed. After stirring for 10 min, the biphasic mixture was partitioned between $\mathrm{CH}_{2} \mathrm{Cl}_{2}(10 \mathrm{~mL})$ and saturated aqueous $\mathrm{NaHCO}_{3}(5 \mathrm{~mL})$. The aqueous phase was separated, extracted with $\mathrm{CH}_{2} \mathrm{Cl}_{2}(3 \times 10 \mathrm{~mL})$ and the combined organic extracts dried $\left(\mathrm{Na}_{2} \mathrm{SO}_{4}\right)$, filtered, and concentrated under reduced pressure to provide a yellow oil. Purification by flash chromatography $\left(\mathrm{SiO}_{2}, \mathrm{EtOAc} /\right.$ hexanes, $1: 3)$ then afforded 12a $(158 \mathrm{mg}, 67 \%)$ : white crystals; mp $100-103{ }^{\circ} \mathrm{C}(\mathrm{EtOAc} /$ hexanes); $R_{f} 0.55$ (EtOAc); FTIR (film) $v_{\max } 1785,1676,1600,1222 \mathrm{~cm}^{-1} ;{ }^{1} \mathrm{H}$ NMR (500 $\left.\mathrm{MHz}, \mathrm{CDCl}_{3}\right) \delta 6.72(\mathrm{~d}, J=9.9 \mathrm{~Hz}, 1 \mathrm{H}), 6.36(\mathrm{dd}, J=1.6,9.9 \mathrm{~Hz}, 1 \mathrm{H}), 5.78(\mathrm{~d}, J=1.6$ $\mathrm{Hz}, 1 \mathrm{H}), 3.84$ (s, $3 \mathrm{H}), 3.74$ (s, $3 \mathrm{H}), 3.15$ (d, $J=13.7 \mathrm{~Hz}, 1 \mathrm{H}), 2.83$ (d, $J=13.7 \mathrm{~Hz}, 1$ 
$\mathrm{H}) ;{ }^{13} \mathrm{C}$ NMR $\left(125 \mathrm{MHz}, \mathrm{CDCl}_{3}\right) \delta 186.7,169.3,163.4,142.2,132.0,105.7,65.4,61.2$, 56.7, 43.8; HRMS-ESI calcd for $\mathrm{C}_{10} \mathrm{H}_{11} \mathrm{NO}_{4} \mathrm{Na}[\mathrm{M}+\mathrm{Na}]^{+} 232.0586$, found 232.0591.

\section{General Procedure B (Preparation of Spirodienones 12 in $\left.\mathrm{CH}_{2} \mathrm{Cl}_{2}-\mathrm{MeOH}\right) .( \pm)-1,6-$ Dimethoxy-1-azaspiro[4.5]deca-6,9-diene-2,8-dione (12c) (Entry 4, Table 1)}

To a suspension of phenyliodine(III) bis(trifluoroacetate) (PIFA) (863 mg, $2.01 \mathrm{mmol}, 1.2$ equiv) in $\mathrm{MeOH}(2 \mathrm{~mL})$, under an atmosphere of $\mathrm{N}_{2}$ at $-78^{\circ} \mathrm{C}$, was added a cold $\left(-78{ }^{\circ} \mathrm{C}\right)$ solution of $10 \mathbf{c}(400 \mathrm{mg}, 1.67 \mathrm{mmol})$ in $\mathrm{CH}_{2} \mathrm{Cl}_{2}(8 \mathrm{~mL})$ via cannula. The reaction mixture was then allowed to warm to $-20{ }^{\circ} \mathrm{C}$ (internal temperature) over $1.5 \mathrm{~h}$ whereupon $\mathrm{H}_{2} \mathrm{O}(3$ $\mathrm{mL}$ ) was added and the cooling bath removed. After stirring for $10 \mathrm{~min}$, the biphasic mixture was partitioned between $\mathrm{CH}_{2} \mathrm{Cl}_{2}(10 \mathrm{~mL})$ and saturated aqueous $\mathrm{NaHCO}_{3}(5 \mathrm{~mL})$. After separation, the aqueous phase was extracted with $\mathrm{CH}_{2} \mathrm{Cl}_{2}(3 \times 10 \mathrm{~mL})$ and the combined organic extracts dried $\left(\mathrm{MgSO}_{4}\right)$, filtered and concentrated under reduced pressure to provide a yellow oil. Purification by flash chromatography over silica gel (EtOAc) then afforded 12c (301 mg, 81\%): white crystals; mp $133-135^{\circ} \mathrm{C}$ (EtOAc/hexanes); $R_{f} 0.24$ (EtOAc); FTIR (film) $v_{\max } 1728,1665,1633,1602,1369,1226 \mathrm{~cm}^{-1} ;{ }^{1} \mathrm{H}$ NMR $\left(400 \mathrm{MHz}, \mathrm{CDCl}_{3}\right) \delta 6.61$ $(\mathrm{d}, J=9.9 \mathrm{~Hz}, 1 \mathrm{H}), 6.28(\mathrm{dd}, J=1.5,9.9 \mathrm{~Hz}, 1 \mathrm{H}), 5.61(\mathrm{~d}, J=1.5 \mathrm{~Hz}, 1 \mathrm{H}), 3.76(\mathrm{~s}, 3 \mathrm{H})$, $3.75(\mathrm{~s}, 3 \mathrm{H}), 2.65-2.55(\mathrm{~m}, 1 \mathrm{H}), 2.48-2.40(\mathrm{~m}, 1 \mathrm{H}), 2.26-2.19(\mathrm{~m}, 1 \mathrm{H}), 2.16-2.08(\mathrm{~m}, 1$ $\mathrm{H}) ;{ }^{13} \mathrm{C}$ NMR $\left(100 \mathrm{MHz}, \mathrm{CDCl}_{3}\right) \delta 186.4,173.2,172.7,144.3,130.3,103.2,64.7,62.8$, 56.2, 27.3, 26.2; HRMS-ESI calcd for $\mathrm{C}_{11} \mathrm{H}_{13} \mathrm{NO}_{4} \mathrm{Na}[\mathrm{M}+\mathrm{Na}]^{+} 246.0742$, found 246.0750.

\section{Methyl ( \pm )-2-Formyl-1-methoxy-5-oxo-pyrrolidine-2-carboxylate (21)}

A stream of oxygen and ozone was passed through a solution of $\mathbf{1 2 c}(83 \mathrm{mg}, 0.37 \mathrm{mmol})$ in $\mathrm{CH}_{2} \mathrm{Cl}_{2}(3 \mathrm{~mL})$ at $-78{ }^{\circ} \mathrm{C}$ for $30 \mathrm{~min}$. The blue solution was then purged with a stream of argon for $5 \mathrm{~min}, \mathrm{Me}_{2} \mathrm{~S}(546 \mu \mathrm{L}, 7.44 \mathrm{mmol})$ added, the cooling bath removed and the mixture stirred room temperature for $12 \mathrm{~h}$. The reaction mixture was then concentrated under reduced pressure and residual oil purified by flash chromatography $\left(\mathrm{SiO}_{2}, \mathrm{EtOAc}\right)$ to provide a crude sample of unstable 21 (45 $\mathrm{mg}, 61 \%$ ): yellow oil; $R_{f} 0.23$ (EtOAc); IR (film) $v_{\max }$ 2951, 1734, 1296, 1246, $1059 \mathrm{~cm}^{-1}$; ${ }^{1} \mathrm{H} \mathrm{NMR}\left(400 \mathrm{MHz}, \mathrm{CDCl}_{3}\right) \delta 9.92(\mathrm{~s}, 1 \mathrm{H}$, CHO), 3.94 (s, $3 \mathrm{H}), 3.89$ (s, $3 \mathrm{H}), 2.49-2.26$ (m, $4 \mathrm{H}) ;{ }^{13} \mathrm{C} \mathrm{NMR}\left(100 \mathrm{MHz}, \mathrm{CDCl}_{3}\right) \delta$ 194.5, 172.6, 168.9, 64.5, 53.5, 42.6, 25.6, 23.3; HRMS-ESI calcd for $\mathrm{C}_{8} \mathrm{H}_{11} \mathrm{NO}_{5} \mathrm{Na}[\mathrm{M}$ $+\mathrm{Na}]^{+} 224.0535$, found 224.0538 .

\section{Methyl $\left(2 S^{\star}, 6 R S^{\star}\right)-2-(H y d r o x y m e t h o x y m e t h y l)-1-m e t h o x y-5-0 x 0-p y r r o l i d i n e-2-c a r b o x y l a t e$ (22)}

A stream of oxygen and ozone was passed through a solution of $12 \mathrm{c}(160 \mathrm{mg}, 0.72 \mathrm{mmol})$ in $\mathrm{MeOH}(5 \mathrm{~mL})$ at $-78^{\circ} \mathrm{C}$ for $30 \mathrm{~min}$. The blue solution was then purged with a stream of argon for $5 \mathrm{~min}$, thiourea ( $68 \mathrm{mg}, 0.90 \mathrm{mmol}, 1.25$ equiv) was added, the cooling bath removed and the solution stirred at room temperature for $5 \mathrm{~h}$. The reaction mixture was then filtered through a pad of Celite and the filtrate concentrated under reduced pressure to provide crude $22(180 \mathrm{mg})$ as an approximately 1:1 mixture of hemiacetal diastereomers (by ${ }^{1} \mathrm{H}$ NMR): colorless oil; $R_{f} 0.50$ (EtOAc); IR (film) $v_{\max } 3373$ (br), 1741, 1702, 1694, $1440,1253,1059 \mathrm{~cm}-1 ;{ }^{1} \mathrm{H}$ NMR $\left(500 \mathrm{MHz}, \mathrm{CD}_{3} \mathrm{OD}\right) \delta$ (mixture of diastereomers) 5.11 (s, $0.5 \mathrm{H}), 5.09$ (s, $0.5 \mathrm{H}), 3.80(\mathrm{~s}, 3.8 \mathrm{H}), 3.79(\mathrm{~s}, 2.2 \mathrm{H}), 3.42(\mathrm{~s}, 1.2 \mathrm{H}), 3.35(\mathrm{~s} 1.5 \mathrm{H})$, 2.35-2.31 (m, $5 \mathrm{H}) ;{ }^{13} \mathrm{C}$ NMR $\left(125 \mathrm{MHz}, \mathrm{CD}_{3} \mathrm{OD}\right) \delta$ (mixture of diastereomers) 174.5, 174.4, 170.8, 170.7, 96.5, 96.3, 71.7, 71.4, 63.4, 63.3, 55.1, 54.8, 52.3, 49.0, 26.2, 26.1, 20.7, 20.1; HRMS-ESI calcd for $\mathrm{C}_{9} \mathrm{H}_{15} \mathrm{NO}_{6} \mathrm{Na}[\mathrm{M}+\mathrm{Na}]^{+} 256.0797$, found 256.0791. 
(士)-2-(Hydroxyiminomethyl)-1-methoxy-5-oxo-pyrrolidine-2-carboxylic acid methyl ester (23)

A stream of oxygen and ozone was passed through a solution of 12c (200 mg, $0.90 \mathrm{mmol})$ in $\mathrm{MeOH}(5 \mathrm{~mL})$ at $-78^{\circ} \mathrm{C}$ for $30 \mathrm{~min}$. The blue solution was then purged with a stream of argon for $10 \mathrm{~min}$, thiourea $(85 \mathrm{mg}, 1.11 \mathrm{mmol})$ added and the mixture then allowed to warm to room temperature over $40 \mathrm{~min}$. Sodium acetate $(132 \mathrm{mg}, 1.61 \mathrm{mmol})$ and $\mathrm{NH}_{2} \mathrm{OH} \cdot \mathrm{HCl}$ (149 $\mathrm{mg}, 2.15 \mathrm{mmol}$ ) were added and the mixture stirred at room temperature for $3 \mathrm{~h}$. The reaction mixture was then concentrated under reduced pressure and the residue purified by flash chromatography $\left(\mathrm{SiO}_{2}\right.$, EtOAc/hexane, 1:1) to provide $\mathbf{2 3}(146 \mathrm{mg}, 75 \%)$ as a 12:1 mixture of geometrical isomers: yellow oil; $R_{f} 0.68$ (EtOAc); IR (film) $v_{\max } 3293$ (br), 1745, $1703,1439,1268,1070,974 \mathrm{~cm}^{-1} ;{ }^{1} \mathrm{H}$ NMR $\left(400 \mathrm{MHz}, \mathrm{CDCl}_{3}\right) \delta$ (major isomer) 8.96 (br $\mathrm{s}, 1 \mathrm{H}), 7.74(\mathrm{~s}, 1 \mathrm{H}), 3.89(\mathrm{~s}, 3 \mathrm{H}), 3.83(\mathrm{~s}, 3 \mathrm{H}), 2.59-2.51(\mathrm{~m}, 1 \mathrm{H}), 2.47-2.42(\mathrm{~m}, 2 \mathrm{H})$, 2.26-2.19 (m, $1 \mathrm{H}) ;{ }^{13} \mathrm{C}$ NMR $\left(100 \mathrm{MHz}, \mathrm{CDCl}_{3}\right) \delta$ (major isomer) $173.1,170.3,145.9$, 68.3, 64.4, 53.5, 26.0, 25.1; HRMS-ESI calcd for $\mathrm{C}_{8} \mathrm{H}_{12} \mathrm{~N}_{2} \mathrm{O}_{5} \mathrm{Na}[\mathrm{M}+\mathrm{Na}]^{+} 239.0644$, found 239.0647.

\section{(士)-2-[(2,4-Dinitrophenyl)-hydrazonomethyl]-1-methoxy-5-oxo-pyrrolidine-2-carboxylic acid methyl ester (24)}

A stream of oxygen and ozone was passed through a solution of $\mathbf{1 2 c}(178 \mathrm{mg}, 0.80 \mathrm{mmol})$ in $\mathrm{MeOH}(4 \mathrm{~mL})$ at $-78^{\circ} \mathrm{C}$ for $30 \mathrm{~min}$. The blue solution was then purged with a stream of argon for $10 \mathrm{~min}$, thiourea $(76 \mathrm{mg}, 1.00 \mathrm{mmol}$ ) added, the cooling bath removed and the solution allowed to warm to room temperature over $40 \mathrm{~min}$. After filtering the reaction mixture through a plug of Celite, the filtrate was sequentially treated with activated $3 \AA$ molecular sieve beads (500 mg), 2,4-dinitrophenylhydrazine (316 $\mathrm{mg}, 1.59 \mathrm{mmol})$ and concentrated $\mathrm{HCl}(300 \mu \mathrm{L})$. The reaction mixture was then heated at reflux for $1.5 \mathrm{~h}$, whereupon it was cooled to room temperature, filtered through a plug of Celite and concentrated under reduced pressure. The resulting oil was purified by flash chromatography $\left(\mathrm{SiO}_{2}, \mathrm{EtOAc} /\right.$ hexanes, 1:5) to provide hydrazone $24(204 \mathrm{mg}, 67 \%)$ : orange crystals; mp $174-176{ }^{\circ} \mathrm{C}$ (EtOAc/hexanes); $R_{f} 0.67$ (EtOAc); FTIR (film) $v_{\max } 3296$ (br), 1735, 1616, 1593, 1514, 1431, 1335, $751 \mathrm{~cm}^{-1} ;{ }^{1} \mathrm{H}$ NMR $\left(500 \mathrm{MHz}, \mathrm{CDCl}_{3}\right) \delta 11.26$ (s, $1 \mathrm{H}), 9.10(\mathrm{~d}, J=2.5 \mathrm{~Hz}, 1 \mathrm{H}), 8.34(\mathrm{dd}, J=2.5,9.5 \mathrm{~Hz}, 1 \mathrm{H}), 7.89(\mathrm{~s}, 1 \mathrm{H}, \mathrm{NH}), 7.87$ (d, $J=9.5 \mathrm{~Hz}, 1 \mathrm{H}), 3.94(\mathrm{~s}, 3 \mathrm{H}), 3.90(\mathrm{~s}, 3 \mathrm{H}), 2.72-2.65(\mathrm{~m}, 1 \mathrm{H}), 2.61-2.45(\mathrm{~m}, 2 \mathrm{H})$, 2.40-2.33 (m, $1 \mathrm{H}) ;{ }^{13} \mathrm{C}$ NMR $\left(100 \mathrm{MHz}, \mathrm{CDCl}_{3}\right) \delta 172.7,170.1,144.6,144.3,138.9,130.3$, $129.8,123.2,116.6,69.3,64.5,53.7,25.9,25.4$; HRMS-ESI calcd for $\mathrm{C}_{14} \mathrm{H}_{14} \mathrm{~N}_{5} \mathrm{O}_{8}[\mathrm{M}-\mathrm{H}]^{-}$ 380.0842 , found 380.0844 .

\section{( \pm )-2-[1,3]Dithiolan-2-yl-1-methoxy-5-oxo-pyrrolidine-2-carboxylic acid methyl ester (26)}

A stream of oxygen and ozone was passed through a solution of $\mathbf{1 2 c}(123 \mathrm{mg}, 0.55 \mathrm{mmol})$ in $\mathrm{MeOH}(3 \mathrm{~mL})$ at $-78^{\circ} \mathrm{C}$ for $30 \mathrm{~min}$. The blue solution was then purged with a stream of argon for $10 \mathrm{~min}$, thiourea (52 $\mathrm{mg}, 0.69 \mathrm{mmol}$ ) added, the cooling bath removed and the solution then allowed to warm to room temperature over $40 \mathrm{~min}$. The reaction mixture was then filtered through a plug of Celite and the filtrate concentrated under reduced pressure. The resulting colorless oil was taken up in $\mathrm{CH}_{2} \mathrm{Cl}_{2}(6 \mathrm{~mL})$ and ethane-1,2-dithiol $(58 \mu \mathrm{L}$, $0.69 \mathrm{mmol})$ and concentrated $\mathrm{HCl}(300 \mu \mathrm{L})$ were added sequentially. The reaction mixture was stirred for $16 \mathrm{~h}$ at room temperature, concentrated under reduced pressure and purified by flash chromatography $\left(\mathrm{SiO}_{2}\right.$, EtOAc/hexanes, 1:5) to provide dithioacetal 26 (72 $\mathrm{mg}$, 47\%): colorless oil; $R_{f} 0.66$ (EtOAc); FTIR (film) $v_{\max } 1735,1433,1271,1057 \mathrm{~cm}^{-1} ;{ }^{1} \mathrm{H}$ NMR (500 MHz, CDCl $) \delta 5.37$ (s, $1 \mathrm{H}), 3.90$ (s, $3 \mathrm{H}), 3.81$ (s, $3 \mathrm{H}), 3.32-3.19(\mathrm{~m}, 4 \mathrm{H})$, 2.51-2.46 (m, $2 \mathrm{H}), 2.38-2.29$ (m, $2 \mathrm{H}) ;{ }^{13} \mathrm{C}$ NMR $\left(125 \mathrm{MHz}, \mathrm{CDCl}_{3}\right) \delta$ 173.6, 171.5, 72.0, 64.2, 55.5, 53.2, 39.4, 39.0, 26.4, 21.8; HRMS-ESI calcd for $\mathrm{C}_{10} \mathrm{H}_{16} \mathrm{NO}_{4} \mathrm{~S}_{2}[\mathrm{M}+\mathrm{H}]^{+}$ 278.0521, found 278.0526. 


\section{Methyl ( \pm )-E-2-(2-Ethoxycarbonylvinyl)-1-methoxy-5-oxo-pyrrolidine-2-carboxylate (27)}

A stream of oxygen and ozone was passed through a solution of $\mathbf{1 2 c}(200 \mathrm{mg}, 0.90 \mathrm{mmol})$ in $\mathrm{MeOH}(5 \mathrm{~mL})$ at $-78^{\circ} \mathrm{C}$ for $30 \mathrm{~min}$. The blue solution was then purged with a stream of argon for $10 \mathrm{~min}$, thiourea $(85 \mathrm{mg}, 1.11 \mathrm{mmol})$ added, the cooling bath removed and the solution then allowed to warm to room temperature over $40 \mathrm{~min}$. The reaction mixture was then concentrated under reduced pressure to provide $\mathbf{2 2}$ as an oil, which was dissolved in toluene $(5 \mathrm{~mL})$. (Carboethoxymethylene)triphenylphosphorane $(687 \mathrm{mg}, 1.97 \mathrm{mmol})$ was then added and the mixture heated at reflux for $2 \mathrm{~h}$. The reaction was then cooled, concentrated under reduced pressure and the resulting oil partitioned between $\mathrm{CH}_{2} \mathrm{Cl}_{2}(10$ $\mathrm{mL})$ and saturated aqueous $\mathrm{NH}_{4} \mathrm{Cl}(7 \mathrm{~mL})$. The organic phase was separated and the aqueous portion extracted with $\mathrm{CH}_{2} \mathrm{Cl}_{2}(3 \times 10 \mathrm{~mL})$, The combined organic extracts were dried $\left(\mathrm{Na}_{2} \mathrm{SO}_{4}\right)$, filtered, concentrated under reduced pressure and the residue purified by flash chromatography $\left(\mathrm{SiO}_{2}\right.$, EtOAc/hexanes, 1:1) to provide $27(213 \mathrm{mg}, 88 \%)$ as a single geometrical isomer: yellow oil; $R_{f} 0.52$ (EtOAc); IR (film) $v_{\max } 1726,1659,1313,1266$, $1184,1053,979 \mathrm{~cm}^{-1} ;{ }^{1} \mathrm{H}$ NMR $\left(400 \mathrm{MHz}, \mathrm{CDCl}_{3}\right) \delta 7.16(\mathrm{~d}, J=16.0 \mathrm{~Hz}, 1 \mathrm{H}), 6.10(\mathrm{~d}, J$ $=16.0 \mathrm{~Hz}, 1 \mathrm{H}), 4.20(\mathrm{q}, J=7.2 \mathrm{~Hz}, 2 \mathrm{H}), 3.93(\mathrm{~s}, 3 \mathrm{H}), 3.82(\mathrm{~s}, 3 \mathrm{H}), 2.44-2.15(\mathrm{~m}, 4 \mathrm{H})$, $1.28(\mathrm{t}, J=7.2 \mathrm{~Hz}, 3 \mathrm{H}) ;{ }^{13} \mathrm{C}$ NMR $\left(100 \mathrm{MHz}, \mathrm{CDCl}_{3}\right) \delta 172.2,170.3,165.5,142.0,123.5$, 69.6, 64.2, 60.9, 53.4, 28.4, 25.7, 14.1; HRMS-ESI calcd for $\mathrm{C}_{12} \mathrm{H}_{17} \mathrm{NO}_{6} \mathrm{Na}[\mathrm{M}+\mathrm{Na}]^{+}$ 294.0954, found 294.0945.

\section{Acetic acid (士)-2-acetoxymethyl-1-methoxy-5-oxo-pyrrolidin-2-ylmethyl ester (29)}

A stream of oxygen and ozone was passed through a solution of $12 \mathrm{c}(148 \mathrm{mg}, 0.66 \mathrm{mmol})$ in $\mathrm{CH}_{2} \mathrm{Cl}_{2}(4 \mathrm{~mL})$ at $-78{ }^{\circ} \mathrm{C}$ for $30 \mathrm{~min}$. The blue solution was then purged with a stream of argon for $10 \mathrm{~min}, \mathrm{Me}_{2} \mathrm{~S}(730 \mu \mathrm{L}, 9.94 \mathrm{mmol})$ added, the cooling bath removed and the mixture stirred at room temperature for $4 \mathrm{~h}$. The reaction mixture was then concentrated under reduced pressure, the residue dissolved in $\mathrm{Et}_{2} \mathrm{O}(5 \mathrm{~mL})$ and this solution then treated with $\mathrm{LiBH}_{4}(72 \mathrm{mg})$. After stirring at room temperature for $16 \mathrm{~h}$, the reaction was quenched with $\mathrm{H}_{2} \mathrm{O}(4 \mathrm{~mL})$ and then stirred for an additional $1 \mathrm{~h}$. The organic layer was then separated and the aqueous layer extracted with EtOAc $(5 \times 10 \mathrm{~mL})$. The combined organic extracts were dried $\left(\mathrm{Na}_{2} \mathrm{SO}_{4}\right)$, filtered through Celite and concentrated under reduced pressure. The resulting solid was dissolved in pyridine $(1 \mathrm{~mL})$ and $\mathrm{Ac}_{2} \mathrm{O}(500 \mu \mathrm{L})$ and this mixture then stirred at room temperature for $24 \mathrm{~h}$. The reaction mixture was then concentrated under reduced pressure and the resulting residue purified by flash chromatography $\left(\mathrm{SiO}_{2}, \mathrm{EtOAc}\right)$ to provide 29 ( $47 \mathrm{mg}, 27 \%$ ): colorless oil; $R_{f} 0.32$ (EtOAc); IR (film) $v_{\max } 1743,1724$, $1225,1045 \mathrm{~cm}^{-1} ;{ }^{1} \mathrm{H}$ NMR $\left(400 \mathrm{MHz}, \mathrm{CDCl}_{3}\right) \delta 4.26(\mathrm{~d}, J=11.6 \mathrm{~Hz}, 2 \mathrm{H}), 4.12(\mathrm{~d}, J=$ $11.6 \mathrm{~Hz}, 2 \mathrm{H}), 3.84$ (s, $3 \mathrm{H}), 2.38$ (m, $2 \mathrm{H}), 2.10$ (s, $6 \mathrm{H}), 2.03$ (m, $2 \mathrm{H}) ;{ }^{13} \mathrm{C}$ NMR (100 $\left.\mathrm{MHz}, \mathrm{CDCl}_{3}\right) \delta 172.4,170.3,64.3,64.2,63.8,26.3,22.6,20.7$; HRMS-ESI calcd for $\mathrm{C}_{11} \mathrm{H}_{17} \mathrm{NO}_{6} \mathrm{Na}[\mathrm{M}+\mathrm{Na}]^{+} 282.0954$, found 282.0958 .

\section{Methyl ( \pm )-2-Hydroxymethyl-1-methoxy-5-oxo-pyrrolidine-2-carboxylate (30c)}

A stream of oxygen and ozone was passed through a solution of $12 \mathrm{c}(139 \mathrm{mg}, 0.62 \mathrm{mmol})$ in $\mathrm{CH}_{2} \mathrm{Cl}_{2}(7 \mathrm{~mL})$ at $-78^{\circ} \mathrm{C}$ for $30 \mathrm{~min}$. The blue solution was then purged with a stream of argon for $10 \mathrm{~min}, \mathrm{Me}_{2} \mathrm{~S}(686 \mu \mathrm{L}, 9.34 \mathrm{mmol})$ added, the cooling bath removed and the mixture stirred at room temperature for $4 \mathrm{~h}$. The reaction mixture was then filtered through a plug of Celite and the filtrate concentrated under reduced pressure. The resulting residue dissolved in $\mathrm{AcOH}(2 \mathrm{~mL})$ and this mixture added to a solution of $\mathrm{NaBH}(\mathrm{OAc})_{3}$ in $\mathrm{AcOH}$ $(0.8 \mathrm{M}, 7.8 \mathrm{~mL})$. After stirring for $24 \mathrm{~h}$ at room temperature, the reaction was concentrated under reduced pressure, the residual oil diluted with $\mathrm{CH}_{2} \mathrm{Cl}_{2}(5 \mathrm{~mL})$ and $2 \mathrm{M}$ aqueous $\mathrm{HCl}$ $(2 \mathrm{~mL})$ added. After standing for $10 \mathrm{~min}$, the organic layer was separated and the aqueous layer extracted with $\mathrm{CH}_{2} \mathrm{Cl}_{2}(3 \times 10 \mathrm{~mL})$. The combined organic extracts were concentrated under reduced pressure and the resulting oil purified by flash chromatography $\left(\mathrm{SiO}_{2}\right.$, EtOAc) to provide 30c $(62 \mathrm{mg}, 49 \%)$ : colorless oil; $R_{f} 0.32$ (EtOAc); FTIR (film) $v_{\max } 3410$ 
(br), 1737, 1706, 1432, 1251, 1056, $969 \mathrm{~cm}^{-1} ;{ }^{1} \mathrm{H} \mathrm{NMR}\left(500 \mathrm{MHz}, \mathrm{CDCl}_{3}\right) \delta 3.97(\mathrm{~d}, J=$ $11.9 \mathrm{~Hz}, 1 \mathrm{H}), 3.87(\mathrm{~d}, J=11.9 \mathrm{~Hz}, 1 \mathrm{H}), 3.84(\mathrm{~s}, 3 \mathrm{H}), 3.73(\mathrm{~s}, 3 \mathrm{H}), 3.35(\mathrm{br} \mathrm{s}, 1 \mathrm{H})$, 2.38-2.34 (m, $2 \mathrm{H}), 2.28-2.22(\mathrm{~m}, 1 \mathrm{H}), 2.08-2.03(\mathrm{~m}, 1 \mathrm{H}) ;{ }^{13} \mathrm{C} \mathrm{NMR}\left(125 \mathrm{MHz}, \mathrm{CDCl}_{3}\right) \delta$ $173.8,172.2,70.0,64.3,62.9,53.2,26.7,24.1$; HRMS-EI calcd for $\mathrm{C}_{8} \mathrm{H}_{14} \mathrm{NO}_{5}[\mathrm{M}+\mathrm{H}]^{+}$ 204.0872, found 204.0881

\section{General Procedure C (Ozonolysis-Reduction of Spirodienones 12). Methyl ( \pm )-2- Hydroxymethyl-1-methoxy-4-oxo-azetidine-2-carboxylate (30a) (Entry 1, Table 2)}

A stream of oxygen and ozone was passed through a solution of 12a $(50 \mathrm{mg}, 0.24 \mathrm{mmol})$ in $\mathrm{MeOH}(3 \mathrm{~mL})$ at $-78^{\circ} \mathrm{C}$ for $30 \mathrm{~min}$. The blue solution was then purged with a stream of argon for $10 \mathrm{~min}$, thiourea $(23 \mathrm{mg}, 0.30 \mathrm{mmol}$ ) was added and the solution then allowed to warm to room temperature over $30 \mathrm{~min}$. After stirring for a additional $10 \mathrm{~min}$, the reaction was concentrated under reduced pressure, the residue dissolved in $\mathrm{AcOH}(500 \mu \mathrm{L})$ and this mixture added to a solution of $\mathrm{NaBH}(\mathrm{OAc})_{3}$ in $\mathrm{AcOH}(0.51 \mathrm{M}, 2 \mathrm{~mL})$. After stirring for 24 $\mathrm{h}$ at room temperature, the reaction was concentrated under reduced pressure, the residual oil diluted with $\mathrm{CH}_{2} \mathrm{Cl}_{2}(5 \mathrm{~mL})$ and $2 \mathrm{M}$ aqueous $\mathrm{HCl}(2 \mathrm{~mL})$ added. After standing for $10 \mathrm{~min}$, the organic layer was separated and the aqueous layer extracted with $\mathrm{CH}_{2} \mathrm{Cl}_{2}(3 \times 10 \mathrm{~mL})$. The combined organic extracts were concentrated under reduced pressure and the resulting oil purified by flash chromatography $\left(\mathrm{SiO}_{2}\right.$, EtOAc) to provide $\mathbf{3 0 a}(35 \mathrm{mg}, 78 \%)$ : colorless oil; $R_{f} 0.44$ (EtOAc); IR (film) $v_{\max } 3445$ (br), 1778, 1742, 1072, $1031 \mathrm{~cm}^{-1} ;{ }^{1} \mathrm{H}$ NMR (400 $\left.\mathrm{MHz}, \mathrm{CDCl}_{3}\right) \delta 4.16(\mathrm{~d}, J=12.4 \mathrm{~Hz}, 1 \mathrm{H}), 4.02(\mathrm{~d}, J=12.4 \mathrm{~Hz}, 1 \mathrm{H}), 3.90\left(\mathrm{~s}, 3 \mathrm{H} ; \mathrm{OCH}_{3}\right)$, $3.84\left(\mathrm{~s}, 3 \mathrm{H} ; \mathrm{OCH}_{3}\right), 2.93(\mathrm{~d}, J=13.8 \mathrm{~Hz}, 1 \mathrm{H}), 2.88(\mathrm{~d}, J=13.8 \mathrm{~Hz}, 1 \mathrm{H}) 2.51$ (br s, 1 $\mathrm{H}) ;{ }^{13} \mathrm{C} \mathrm{NMR}\left(100 \mathrm{MHz}, \mathrm{CDCl}_{3}\right) \delta 170.3,164.4,67.5,65.0,61.4,53.0,39.6$; HRMS-ESI calcd for $\mathrm{C}_{7} \mathrm{H}_{11} \mathrm{NO}_{5} \mathrm{Na}[\mathrm{M}+\mathrm{Na}]^{+} 212.0535$, found 212.0543 .

\section{General Procedure D (Ozonolysis-Reduction-Acetylation of Spirodienones 12). Methyl (士)-2-Acetoxymethyl-1-methoxy-6-oxo-piperidine-2-carboxylate (30e) (Entry 5, Table 2)}

A stream of oxygen and ozone was passed through a solution of $12 \mathbf{e}(50 \mathrm{mg}, 0.21 \mathrm{mmol})$ in $\mathrm{MeOH}(5 \mathrm{~mL})$ at $-78{ }^{\circ} \mathrm{C}$ for $3 \mathrm{~h}$. The blue solution was then purged with a stream of argon for $10 \mathrm{~min}$, thiourea $(20 \mathrm{mg}, 0.26 \mathrm{mmol}$ ) was added in one portion and the solution then allowed to warm to room temperature over $30 \mathrm{~min}$. After stirring for an additional $10 \mathrm{~min}$, the reaction was concentrated under reduced pressure, the residue dissolved in $\mathrm{AcOH}$ (500 $\mu \mathrm{L})$. This solution was added to a solution of $\mathrm{NaBH}(\mathrm{OAc})_{3}$ in $\mathrm{AcOH}(0.17 \mathrm{M}, 5 \mathrm{~mL})$. After stirring for $24 \mathrm{~h}$ at room temperature, the reaction was concentrated under reduced pressure and the residue dissolved in pyridine $(1 \mathrm{~mL})$ and acetic anhydride $(500 \mu \mathrm{L}, 5 \mathrm{mmol})$. The mixture was stirred at room temperature for $8 \mathrm{~h}$, then concentrated under reduced pressure and the residue purified by flash chromatography $\left(\mathrm{SiO}_{2}, \mathrm{EtOAc}\right)$ to provide $30 \mathrm{e}(32 \mathrm{mg}$, $58 \%$ ) and starting material 12e (18 mg): white crystals; mp 72-74 ${ }^{\circ} \mathrm{C}$ (EtOAc/hexanes); $R_{f}$ 0.37 (EtOAc); FTIR (film) $v_{\max } 1745,1689,1238,1051 \mathrm{~cm}^{-1} ;{ }^{1} \mathrm{H}$ NMR $\left(500 \mathrm{MHz}, \mathrm{CDCl}_{3}\right)$ $\delta 4.54(\mathrm{~d}, J=11.9 \mathrm{~Hz}, 1 \mathrm{H}), 4.49$ (d, $J=11.9 \mathrm{~Hz}, 1 \mathrm{H}), 3.79$ (s, $3 \mathrm{H}), 3.78$ (s, $3 \mathrm{H})$, 2.54-2.47 (m, $2 \mathrm{H}), 2.19-2.16(\mathrm{~m}, 1 \mathrm{H}), 2.12(\mathrm{~s}, 3 \mathrm{H}), 2.11-2.05(\mathrm{~m}, 1 \mathrm{H}), 1.82-1.78(\mathrm{~m} 2$ $\mathrm{H}) ;{ }^{13} \mathrm{C}$ NMR (125 MHz, CD $\left.\mathrm{OD}\right) \delta 171.0(2 \mathrm{C}), 170.7,70.9,63.9,63.7,53.5,33.5,31.3$, 21.2, 18.1; HRMS-ESI calcd for $\mathrm{C}_{11} \mathrm{H}_{17} \mathrm{NO}_{6} \mathrm{Na}[\mathrm{M}+\mathrm{Na}]^{+} 282.0954$, found 282.0958.

\section{General Procedure E (Luche Reduction-Ozonolysis of Spirodienones 12). Methyl (2S*, $\left.4 S^{\star}\right)$-2-Hydroxymethyl-1-methoxy-5-oxo-4-phenyl-pyrrolidine-2-carboxylate (30j) (Entry 10, Table 2)}

To a solution of $\mathbf{1 2 \mathbf { j }}(117 \mathrm{mg}, 0.39 \mathrm{mmol})$ and $\mathrm{CeCl}_{3} \cdot 7 \mathrm{H}_{2} \mathrm{O}(117 \mathrm{mg}, 0.39 \mathrm{mmol})$ in $\mathrm{MeOH}$ $(8 \mathrm{~mL})$ at $0{ }^{\circ} \mathrm{C}$ was added $\mathrm{NaBH}_{4}(16 \mathrm{mg}, 0.41 \mathrm{mmol})$. After stirring for $1 \mathrm{~min}$, the reaction was quenched with water $(2 \mathrm{~mL})$, concentrated under reduced pressure and remaining aqueous portion extracted with $\mathrm{CH}_{2} \mathrm{Cl}_{2}(3 \times 10 \mathrm{~mL})$. The combined organic extracts were dried $\left(\mathrm{Na}_{2} \mathrm{SO}_{4}\right)$, filtered and concentrated to provide the unstable dienylic alcohol as a 
colorless oil, which was immediately subjected to ozonolysis. Thus, a stream of oxygen and ozone was passed through a solution of the dienylic alcohol in $\mathrm{MeOH}(4 \mathrm{~mL})$ at $-78{ }^{\circ} \mathrm{C}$ for $30 \mathrm{~min}$. The blue solution was then purged with a stream of argon for $10 \mathrm{~min}$, thiourea (37 $\mathrm{mg}, 0.49 \mathrm{mmol}, 1.25$ equiv) was added and the solution then allowed to warm to room temperature over $30 \mathrm{~min}$. After stirring for an additional $30 \mathrm{~min}$, the reaction was concentrated under reduced pressure, the residue dissolved in $\mathrm{AcOH}(1 \mathrm{~mL})$ and this mixture added to a solution of $\mathrm{NaBH}(\mathrm{OAc})_{3}$ in $\mathrm{AcOH}(0.65 \mathrm{M}, 3 \mathrm{~mL}, 5$ equiv). After stirring for $24 \mathrm{~h}$ at room temperature, the reaction was concentrated under reduced pressure, the residual oil diluted with $\mathrm{CH}_{2} \mathrm{Cl}_{2}(10 \mathrm{~mL})$ and $2 \mathrm{M}$ aqueous $\mathrm{HCl}(5 \mathrm{~mL})$ added. After standing for $20 \mathrm{~min}$, the organic layer was separated and the aqueous layer extracted with $\mathrm{CH}_{2} \mathrm{Cl}_{2}(3 \times 15 \mathrm{~mL})$. The combined organic extracts were concentrated under reduced pressure and the resulting oil purified by flash chromatography $\left(\mathrm{SiO}_{2}, \mathrm{EtOAc}\right)$ to provide 30j (107 mg, 98\%).

\section{General Procedure F (Reductive Cleavage of $\mathrm{N}$-Methoxy Lactams). Methyl ( \pm )-2- Hydroxymethyl-4-oxo-azetidine-2-carboxylate (32a) (Entry 1, Table 4)}

A mixture of 30a $(210 \mathrm{mg}, 1.11 \mathrm{mmol})$ and $\mathrm{Mo}(\mathrm{CO})_{6}(352 \mathrm{mg}, 1.33 \mathrm{mmol}, 1.2$ equiv) in degassed $\mathrm{CH}_{3} \mathrm{CN}-\mathrm{H}_{2} \mathrm{O}(15: 1,5 \mathrm{~mL})$ was heated at reflux, under $\mathrm{N}_{2}$, for $24 \mathrm{~h}$, whereupon the black reaction mixture was cooled to room temperature, opened to the atmosphere and stirred for $24 \mathrm{~h}$. The reaction was then concentrated under reduced pressure and the resulting residue purified by flash chromatography $\left(\mathrm{SiO}_{2}, \mathrm{EtOAc}\right)$ to yield 32a $(133 \mathrm{mg}, 75 \%)$ : colorless oil; $R_{f} 0.37$ (EtOAc); FTIR (film) $v_{\max } 3312$ (br), 1750, 1277, 1228, 1045 $\mathrm{cm}^{-1} ;{ }_{1}^{1} \mathrm{H} \mathrm{NMR}\left(400 \mathrm{MHz}, \mathrm{CDCl}_{3}\right) \delta 6.80(\mathrm{br} \mathrm{s}, 1 \mathrm{H}), 4.14(\mathrm{~d}, J=11.7 \mathrm{~Hz}, 1 \mathrm{H}), 3.85-3.82$ $(\mathrm{m}, 4 \mathrm{H}), 3.12(\mathrm{~d}, J=14.9 \mathrm{~Hz}, 1 \mathrm{H}), 3.04(\mathrm{~d}, J=14.9 \mathrm{~Hz}, 1 \mathrm{H}), 2.71(\mathrm{br} \mathrm{s}, 1 \mathrm{H}) ;{ }^{13} \mathrm{C}$ NMR $\left(100 \mathrm{MHz}, \mathrm{CD}_{3} \mathrm{OD}\right) \delta 172.4,167.1,65.1,59.3,53.5,45.2$; HRMS-ESI calcd for $\mathrm{C}_{6} \mathrm{H}_{9} \mathrm{NO}_{4}$ $[\mathrm{M}+\mathrm{Na}]^{+} 182.0429$, found 182.0426 .

\section{General Procedure G (Hydrogenolysis of $\mathrm{N}$-Benzyloxy Lactams). Methyl ( \pm )-1-Hydroxy-2- hydroxymethyl-4-oxo-azetidine-2-carboxylate (34b) (Entry 1, Table 5)}

A mixture of $\mathbf{3 0 b}(40 \mathrm{mg}, 0.15 \mathrm{mmol})$ and $10 \% \mathrm{Pd} / \mathrm{C}(2 \mathrm{mg})$ in EtOAc $(2 \mathrm{~mL})$ was stirred under an atmosphere of $\mathrm{H}_{2}$ for $10 \mathrm{~min}$ then filtered through a pad of Celite. The filtrate was concentrated under reduced pressure and the residue purified by flash chromatography $\left(\mathrm{SiO}_{2}, \mathrm{EtOAc}\right)$ to yield $\mathbf{3 4 b}(26 \mathrm{mg}, 99 \%)$ : colorless oil; $R_{f} 0.25$ (EtOAc); FTIR (film) $v_{\max }$ 3390 (br), 1770, 1745, 1247, $1037 \mathrm{~cm}^{-1} ;{ }^{1} \mathrm{H}$ NMR (400 MHz, CD $\left.{ }_{3} \mathrm{OD}\right) \delta 4.02$ (d, $J=12.4$ $\mathrm{Hz}, 1 \mathrm{H}), 3.95(\mathrm{~d}, J=12.4 \mathrm{~Hz}, 1 \mathrm{H}), 3.79(\mathrm{~s}, 3 \mathrm{H}), 2.89(\mathrm{~d}, J=13.2 \mathrm{~Hz}, 1 \mathrm{H}), 2.82(\mathrm{~d}, J=$ $13.2 \mathrm{~Hz}, 1 \mathrm{H}) ;{ }^{13} \mathrm{C}$ NMR $\left(100 \mathrm{MHz}, \mathrm{CD}_{3} \mathrm{OD}\right) \delta 170.0,164.7,67.9,58.4,51.7,38.0$; HRMSESI calcd for $\mathrm{C}_{6} \mathrm{H}_{9} \mathrm{NO}_{5} \mathrm{Na}[\mathrm{M}+\mathrm{Na}]^{+}$198.0378, found 198.0373 .

\section{Supplementary Material}

Refer to Web version on PubMed Central for supplementary material.

\section{Acknowledgments}

We thank the National Institutes of Health (GM-67176) for financial support.

\section{References and Footnotes}

1. Ho, T-L. Tactics of Organic Synthesis. 1st ed.. New York: Wiley; 1994. p. 50-53.

2. (a) Woodward RB, Cava MP, Ollis WD, Hunger A, Daeniker HU, Schenker K. J. Am. Chem. Soc. 1954; 76:4749.(b) Woodward RB, Cava MP, Ollis WD, Hunger A, Daeniker HU, Schenker K. Tetrahedron. 1963; 19:247. 
3. For recent, representative reports concerning the oxidative degradation of benzenoid systems, see: (a) Audouard C, Barsukov I, Fawcett J, Griffith GA, Percy JM, Pintat S, Smith CA. Chem. Commun. 2004:1526. (b) Lee YS, Choung WK, Kim KH, Kang TW, Ha DC. Tetrahedron. 2004; 60:867. (c) Miranda LSM, Vasconcellos MLAA. Synthesis. 2004:1767. (d) Demir A, Sesenoglu O, Ulku D, Arici C. Helv. Chim. Acta. 2003; 86:91. (e) Jaroch S, Holscher P, Rehwinkel H, Sulzle D, Burton G, Hillmann M, McDonald FM. Bioorg. Med. Chem. Lett. 2003; 13:1981. [PubMed: 12781178] (f) Mander LN, Williams CM. Tetrahedron. 2003; 59:1105. and references therein. (g) Colletti SL, Li C, Fisher MH, Wyvratt MJ, Meinke PT. Tetrahedron Lett. 2000; 41:7825. (h) Bringmann G, Munchbach M, Michel M. Tetrahedron: Asymmetry. 2000; 11:3167. (i) Zhou W-S, Lu Z-H, Xu Y-M, Liao L-X, Wang Z-M. Tetrahedron. 1999; 55:11959.

4. Birch AJ, Fitton F, Smith DCC, Steere DE, Stelfox AR. J. Chem. Soc. 1963:2209.

5. (a) Evans DA, Sjogren EB. Tetrahedron Lett. 1986; 27:3119.(b) Evans DA, Gauchet-Prunet JA, Carreira EM, Charette AB. J. Org. Chem. 1991; 56:741.(c) Rao AVR, Gurjar MK, Islam A. Tetrahedron Lett. 1993; 34:4993.

6. (a) Corey EJ, Katzenellenbogen JA, Gilman NW, Roman SA, Erickson BWJ. J. Am. Chem. Soc. 1968; 90:5618.(b) Moody CJ, Toczek J. Tetrahedron Lett. 1986; 27:5253.(c) Moody CJ, Toczek J. J. Chem. Soc.-Perkin Trans. 1. 1988:1397.(d) Kammler R, Polborn K, Wanner KT. Tetrahedron. 2003; 59:3359.

7. (a) Mittelbach M, Poklukar N, Junek H. Liebigs Ann. Chem. 1990:185.(b) Bringmann G, Kuenkel G, Geuder T. Synlett. 1990:253.(c) Bringmann G, Geuder T. Synthesis. 1991:829.

8. (a) Wipf P, Lim S. J. Am. Chem. Soc. 1995; 117:558.(b) Wipf P, Reeves JT. Chem. Commun. 2002:2066.(c) Jung IC. Eur. J. Org. Chem. 2001:1899.

9. (a) Zvilichovsky G, Gurvich V. J. Chem. Soc. Perkin Trans. 1. 1995:2509.(b) Zvilichovsky G, Gurvich V. J. Chem. Soc. Perkin Trans. 1. 1997:1069.(c) Zvilichovsky G, Gurvich V. Tetrahedron. 1995; 51:5479.(d) Gbara-Haj-Yahia I, Zvilichovsky G, Seri N. J. Org. Chem. 2004; 69:4135. [PubMed: 15176839]

10. (a) Kirkemo CL, White JD. J. Org. Chem. 1985; 50:1316.(b) Bringmann G. Liebigs Ann., Chem. 1985:2105.

11. For reports concerning the ozonolysis of 2,5-cyclohexadienones, see: (a) Caspi E, Schmid W, Khan BT. Tetrahedron. 1962; 18:767. (b) Caspi E, Khan BT, Balasubrahmanyam SN. Tetrahedron. 1962; 18:1013. (c) Balasubrahmanyam SN, Caspi E, Khan BT. J. Chem. Soc. 1963:761. (d) Rodig OR, Zanati G. J. Org. Chem. 1968; 33:914. (e) Okamoto K, Nitta I, Shingu H. Bull. Chem. Soc. Jpn. 1970; 43:1768. (f) Bailey PS, Ferrell TM. J. Org. Chem. 1981; 46:5028.

12. (a) Harries C, Turk H. Chem. Ber. 1905; 374:1630. (b) Harries C. Ann. 1910; 374:288. (c) For an account of Harries' introduction of ozone into organic chemistry, see: Rubin MB. Helv. Chim. Acta. 2003; 86:930.

13. Bailey, PS. Ozonation in Organic Chemistry. Trahanovsky, W., editor. Vol. Vol. 1. New York: Academic Press; 1978. p. 153-162.Vol. I

14. Story PR, Burgess JR. Tetrahedron Lett. 1968:1287.

15. (a) Shibata K, Takegawa S, Koizumi N, Yamakoshi N, Shimazawa E. Chem. Pharm. Bull. 1992; 40:935. [PubMed: 1381997] (b) Koizumi N, Takegawa S, Mieda M, Shibata K. Chem. Pharm. Bull. 1996; 44:2162. [PubMed: 8945781] (c) Cambie RC, Higgs PI, Read CM, Rutledge PS, Ryan GR, Woodgate PD. Aust. J. Chem. 1990; 43:681.

16. For reviews covering the formation of quaternary stereogenic center, see: (a) Christoffers J, Mann A. Angew. Chem. Int. Ed. 2001; 40:4591. (b) Corey EJ, Guzman-Perez A. Angew. Chem. Int. Ed. 1998; 37:388.

17. For recent reviews of phenolic oxidation, see: (a)Wirth T. Wirth T. Hypervalent Iodine Chemistry: Modern Developments in Organic Synthesis. 2003; Vol. 224BerlinSpringer (b) Moriarty RM, Prakash O. Org. React. 2001; 57:327. (c) Pelter A, Ward RS. Tetrahedron. 2001; 57:273.

18. (a) Wardrop DJ, Basak A. Org. Lett. 2001; 3:1053. [PubMed: 11277793] (b) Wardrop DJ, Zhang W. Org. Lett. 2001; 3:2353. [PubMed: 11463314] (c) Wardrop DJ, Landrie CL, Ortíz JA. Synlett. 2003:1352.

19. For reviews concerning the chemistry of nitrenium ions, see: (a)Falvey DE. Moss RA, Platz MS, Jones M. Reactive Intermediate Chemistry. 2004; Chapter 13Hoboken, NJWiley-Interscience (b) 
Kikugawa Y. Rev. Heteroatom Chem. 1996; 15:263. (c)Abramovitch RA, Jeyaraman R. Scriven EFV. Azides and Nitrenes: Reactivity and Utility. 1984; Chapter 6Orlando, FLAcademic Press

20. For the intramolecular reaction acylnitrenium ions and related electron-deficient species with arenes, see: (a) Glover SA, Goosen A, McCleland CW, Schoonraad JL. J. Chem. Soc. Perkin Trans. 1. 1984:2255. (b) Kikugawa Y, Kawase M. J. Am. Chem. Soc. 1984; 106:5728. (c) Glover SA, Goosen A, McCleland CW, Schoonraad JL. Tetrahedron. 1987; 43:2577. (d) Kawase M, Kitamura T, Kikugawa Y. J. Org. Chem. 1989; 54:3394. (e) Cherest M, Lusinchi X. Tetrahedron Lett. 1989; 30:715. (f) Glover SA, Rowbottom CA, Scott AP, Schoonraad JL. Tetrahedron. 1990; 46:7247. (g) Prata JV, Clemente DTS, Prabhakar S, Lobo AM, Mourato I, Branco PS. J. Chem. Soc. Perkin Trans. 1. 2002:513. (h) Miyazawa E, Sakamoto T, Kikugawa Y. Heterocycles. 2003; 59:149. (i) Miyazawa E, Sakamoto T, Kikugawa Y. J. Org. Chem. 2003; 68:5429. [PubMed: 12816516] (j) Kikugawa Y, Nagashima A, Sakamoto T, Miyazawa E, Shiiya M. J. Org. Chem. 2003; 68:6739. [PubMed: 12919042]

21. Wardrop DJ, Burge MS, Zhang W, Ortíz JA. Tetrahedron. Lett. 2003; 44:2587.

22. Sakai R, Oiwa C, Takaishi K, Kamiya H, Tagawa M. Tetrahedron Lett. 1999; 40:6941.

23. For syntheses of dysibetaine, see: (a) Langlois N, Le Nguyen BK. J. Org. Chem. 2004; 69:7558. [PubMed: 15497982] (b) Le Nguyen BK, Langlois N. Tetrahedron Lett. 2003; 44:5961. (c) Snider BB, Gu Y. Org. Lett. 2001; 3:1761. [PubMed: 11405705]

24. (a) Shin-ya K, Kim JS, Furihata K, Hayakawa Y, Seto H. Tetrahedron Lett. 1997; 38:7079.(b) Okue M, Kobayashi H, Shin-ya K, Furihata K, Hayakawa Y, Seto H, Watanabe H, Kitahara T. Tetrahedron Lett. 2002; 43:857.

25. Feling RH, Buchanan GO, Mincer TJ, Kauffman CA, Jensen PR, Fenical W. Angew. Chem. Int. Ed. 2003; 42:355.

26. (a) Gordon EM, Ondetti MA, Pluscec J, Cimarusti CM, Bonner DP, Sykes RB. J. Am. Chem. Soc. 1982; 104:6053.(b) Koster, WH.; Bonner, DP. Frontiers of Antibiotic Research. Umezawa, H., editor. New York: Academic Press; 1987. p. 211

27. Wardrop DJ, Burge MS. Chem. Commun. 2004:1230.

28. (a) Clark RD, Heathcock CH. J. Org. Chem. 1976; 41:1396. [PubMed: 1263006] (b) Keul H, Kuczkowski RL. J. Am. Chem. Soc. 1984; 106:5370.(c) Keul H, Kuczkowski RL, Choi HS. J. Org. Chem. 1985; 50:3365.(d) Wojciechowski BJ, Pearson WH, Kuczkowski RL. J. Org. Chem. 1989; 54:115.(e) Griesbaum K, Kim WS, Nakamura N, Mori M, Nojima M, Kusabayashi S. J. Org. Chem. 1990; 55:6153.(f) Bunnelle WH. Chem. Rev. 1991; 91:335.(g) Griesbaum K, Kim WS. J. Org. Chem. 1992; 57:5574.(h) Hillers S, Niklaus A, Reiser O. J. Org. Chem. 1993; 58:3169.(i) Schank K, Beck H, Pistorius S. Helv. Chim. Acta. 2004; 87:2025.

29. For reports of the efficient ozonolysis of dihydropyrones, see: (a) Danishefsky S, Kato N, Askin D, Kerwin JF Jr. J. Am. Chem. Soc. 1982; 104:360. (b) Sugiyama T, Yamakoshi H, Nojima M. J. Org. Chem. 1993; 58:4212.

30. For details of the preparation of $\mathbf{1 0}$, see Supporting Information.

31. (a) In the case of substrate 10a (entry 1 ), the formation of $\beta$-lactam 12a was also accompanied by compound 20 which arises from the conjugate addition of methanol to the dienone system. $31 \mathrm{~b}$ Although isolated as a single diastereomer, we were unable to unequivocally establish the relative stereochemistry of $\mathbf{2 0}$ via spectroscopic means. The formation of this undesired by-product was simply avoided by carrying out the cyclization of $\mathbf{1 0 a}$ and $\mathbf{1 0 b}$ in $\mathrm{CH}_{2} \mathrm{Cl}_{2}$, in the absence of methanol (entries 2 and 3). 


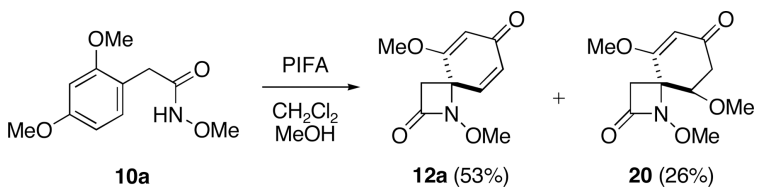

Nilsson A, Ronlán A, Parker VD. Tetrahedron Lett. 1975:1107.

32. Hoffmann RW. Chem. Rev. 1989; 89:1841.

33. Analogous rationalizations of $\pi$-facial diastereoselectivity are proposed in: (a) Wender PA, Ternansky RJ. Tetrahedron Lett. 1985; 26:2625. (b) Adam W, Peters EM, Peters K, Prein M, von Schnering HG. J. Am. Chem. Soc. 1995; 117:6686. (c) Kamikawa K, Furusyo M, Uno T, Sato Y, Konoo A, Bringmann G, Uemura M. Org. Lett. 2001; 3:3667. [PubMed: 11700108]

34. The oxidative $\mathrm{Ar}_{2}-5$ cyclization of 3-substituted 3-aryl-1-benzyloxy ureas has previously been noted: Romero AG, Darlington WH, Jacobsen EJ, Mickelson JW. Tetrahedron Lett. 1996; 37:2361. (footnote 7).

35. For examples of biologically active $N$-hydroxy lactams and their derivatives, see: (a) Higashide E, Horii S, Ono H, Mizokami N, Yamazaki T, Shibata M, Yoneda M. J. Antibiot. 1985; 38:285. [PubMed: 3839222] (b) Schlemminger I, Mole DR, McNeill LA, Dhanda A, Hewitson KS, Tian YM, Ratcliffe PJ, Pugh CW, Schofield CJ. Bioorg. Med. Chem. Lett. 2003; 13:1451. [PubMed: 12668010] (c) Wendenbaum S, Demange P, Dell A, Meyer JM, Abdallah MA. Tetrahedron Lett. 1983; 24:4877. (d) Swarén P, Massova I, Bellettini JR, Bulychev A, Maveyraud L, Kotra LP, Miller MJ, Mobashery S, Samama JP. J. Am. Chem. Soc. 1999; 121:5353. (e) Bulychev A, O'Brien ME, Massova I, Teng M, Gibson TA, Miller MJ, Mobashery S. J. Am. Chem. Soc. 1995; 117:5938. (f) Bulychev A, Bellettini JR, O'Brien M, Crocker PJ, Samama JP, Miller MJ, Mobashery S. Tetrahedron. 2000; 56:5719.

36. Schreiber SL, Claus RE, Reagan J. Tetrahedron Lett. 1982; 23:3867.

37. Gupta D, Soman R, Dev S. Tetrahedron. 1982; 38:3013.

38. Duhamel P, Kotera M, Monteil T, Marabout B, Davoust D. J. Org. Chem. 1989; 54:4419.

39. The instablity of related systems to basic conditions has been noted: (a) Reddy LR, Saravanan P, Corey EJ. J. Am. Chem. Soc. 2004; 126:6230. [PubMed: 15149210] (b) Trancard D, Tout JB, Giard T, Chichaoui I, Cahard D, Plaquevent JC. Tetrahedron Lett. 2000; 41:3843. (c) Duhamel P, Kotera M. J. Org. Chem. 1982; 47:1688.

40. Bis(hydroxymethyl)pyrrolidinones and their derivatives are of interest as neuraminidase inhibitors: (a) Brouillette WJ, Bajpai SN, Ali SM, Velu SE, Atigadda VR, Lommer BS, Finley JB, Luo M, Air GM. Bioorg. Med. Chem. 2003; 11:2739. [PubMed: 12788348] (b) Schieweck F, Altenbach HJ. J. Chem. Soc. Perkin Trans. 1. 2001:3409. (c) Atigadda VR, Brouillette WJ, Duarte F, Ali SM, Babu YS, Bantia S, Chand P, Chu N, Montgomery JA, Walsh DA, Sudbeck EA, Finley J, Luo M, Air GM, Laver GW. J. Med. Chem. 1999; 42:2332. [PubMed: 10395473]

41. (a) Ishmuratov GY, Kharisov RY, Yakovleva MP, Botsman OV, Muslukhov RR, Tolstikov GA. Russ. J. Org. Chem. 2001; 37:37.(b) Gribble GW. Chem. Soc. Rev. 1998; 27:395.

42. Zhang J, Flippen-Anderson JL, Kozikowski AP. J. Org. Chem. 2001; 66:7555. [PubMed: 11681981]

43. For selected routes to 4,4-disubtituted azetidinones, see: (a) Ageno G, Banfi L, Cascio G, Guanti G, Manghisi E, Riva R, Rocca V. Tetrahedron. 1995; 51:8121. (b) DeKimpe N, Tehrani KA, Fonck G. J. Org. Chem. 1996; 61:6500. [PubMed: 11667512] (c) Palomo C, Aizpurua JM, Garc $\square$ a JM, Galarza R, Legido M, Urchegui R, Román P, Luque A, Server-Carrio J, Linden A. J. Org. Chem. 1997; 62:2070. [PubMed: 11671511] (d) Gerona-Navarro G, Garcia-López MT, 
González-Mniz R. J. Org. Chem. 2002; 67:3953. [PubMed: 12027724] (e) Campomanes P, Menendez MI, Sordo TL. J. Org. Chem. 2003; 68:6685. [PubMed: 12919033]

44. For the preparation of quaternary tetrahydroisoquinoline-3-carboxylic acid derivatives, see: (a) Vicario JL, Badia D, Carrillo L, Etxebarria J. Curr. Org. Chem. 2003; 7:1775. (b) Kawabata T, Ozturk O, Suzuki H, Fuji K. Synthesis. 2003:505. (c) Alezra V, Bonin M, Micouin L, Husson HP. Tetrahedron Lett. 2001; 42:2111. (d) Chinchilla R, Galindo N, Najera C. Synthesis. 1999:704. (e) Ma D, Ma Z, Kozikowski AP, Pshenichkin S, Wroblewski JT. Bioorg. Med. Chem. Lett. 1998; 8:2447. [PubMed: 9873559] (f) Seebach D, Dziadulewicz E, Behrendt L, Cantoreggi S, Fitzi R. Liebigs Ann. Chem. 1989:1215. (g) Bajgrowicz J, El Achquar A, Roumestant ML, Pigie`re C, Viallefont P. Heterocycles. 1986; 24:2165.

45. (a) Kondo K, Sodeoka M, Mori M, Shibasaki M. Tetrahedron Lett. 1993; 34:4219.(b) Kondo K, Sodeoka M, Mori M, Shibasaki M. Synthesis. 1993:920.(c) Wipf P, Kim Y. J. Am. Chem. Soc. 1994; 116:11678.(d) Blades K, Cockerill GS, Easterfield HJ, Lequeux TP, Percy JM. Chem. Commun. 1996:1615.

46. Banerjee AK, Azocar JA, Vera W. Synth. Commun. 1999; 29:2995.

47. (a) Luche JL. J. Am. Chem. Soc. 1978; 100:2226.(b) Abruscato GJ, Tidwell TT. J. Org. Chem. $1972 ; 37: 4151$.

48. Acetylation of the crude product was necessary in this case to facilitate chromatographic purification.

49. Nakagawa TW, Andrews LJ, Keefer RM. J. Am. Chem. Soc. 1960; 82:269.

50. (a) Wipf P, Jung JK. Chem. Rev. 1999; 99:1469. [PubMed: 11749453] (b) Ohkata K, Tamura Y, Shetuni BB, Takagi R, Miyanaga W, Kojima S, Paquette LA. J. Am. Chem. Soc. 2004; 126:16783. [PubMed: 15612717]

51. The calculations were performed with Spartan'04 for Macintosh, Wavefunction Inc. Irvine, CA 4024

52. Mattingly PG, Miller MJ. J. Org. Chem. 1980; 45:410.

53. (a) Chang CY, Yang TK. Tetrahedron-Asymmetry. 2003; 14:2081.(b) Romero AG, Darlington WH, McMillan MW. J. Org. Chem. 1997; 62:6582.

54. Qabar MN, Kahn M. Tetrahedron Lett. 1996; 37:965.

55. (a) Chiara JL, Destabel C, Gallego P, Marco-Contelles J. J. Org. Chem. 1996; 61:359.(b) Yang HW, Romo D. J. Org. Chem. 1999; 64:7657.(c) Keck GE, Wager TT, McHardy SF. Tetrahedron. 1999; 55:11755.

56. (a) Naruse M, Aoyagi S, Kibayashi C. J. Org. Chem. 1994; 59:1358.(b) Blakemore PR, Kim SK, Schulze VK, White JD, Yokochi AFT. J. Chem. Soc. Perkin Trans. 1. 2001:1831.(c) Chow CP, Shea KJ, Sparks SM. Org. Lett. 2002; 4:2637. [PubMed: 12153197]

57. (a) King SB, Ganem B. J. Am. Chem. Soc. 1991; 113:5089.(b) Malpass JR, Smith C. Tetrahedron Lett. 1992; 33:273.

58. (a) Graham SL, Scholz TH. Tetrahedron Lett. 1990; 31:6269.(b) Anderson JC, Flaherty A, Swarbrick ME. J. Org. Chem. 2000; 65:9152. [PubMed: 11149863]

59. Keck GE, McHardy SF, Murry JA. Tetrahedron Lett. 1994; 34:6215.

60. Yus M, Radivoy G, Alonso F. Synthesis. 2001:914.

61. (a) Cardani S, Gennari C, Scolastico C, Villa R. Tetrahedron. 1989; 45:7397.(b) Williams RM, Lee BH, Miller MM, Anderson OP. J. Am. Chem. Soc. 1989; 111:1073.

62. (a) Cicchi S, Goti A, Brandi A, Guarna A, De Sarlo F. Tetrahedron Lett. 1990; 31:3351.(b) Gouverneur V, Ghosez L. Tetrahedron Lett. 1991; 32:5349.(c) Ritter AR, Miller MJ. J. Org. Chem. 1994; 59:4602.

63. (a) Black DSC, Brown RFC, Wade AM. Aust. J. Chem. 1972; 25:2155.(b) Black DSC, Brown RFC, Wade AM. Aust. J. Chem. 1972; 25:2429.(c) Keck GE, Webb RR, Yates JB. Tetrahedron. 1981; 37:4007.(d) Crossley MJ, Crumbie RL, Fung YM, Potter JJ, Pegler MA. Tetrahedron Lett. 1987; 28:2883.(e) Baldwin JE, Adlington RM, Gollins DW, Schofield CJ. J. Chem. Soc. Chem. Commun. 1990:720.(f) Baldwin JE, Adlington RM, Godfrey CRA, Gollins DW, Schofield CJ. Tetrahedron. 1991; 47:5835.(g) Leeson PD, Williams BJ, Rowley M, Moore KW, Baker R, Kemp JA, Priestley T, Foster AC, Donald AE. Bioorg. Med. Chem. Lett. 1993; 3:71.(h) Tiecco M, Testaferri L, Tingoli M, Marini F. J. Chem. Soc. Chem. Commun. 1994:221.(i) Thomas A, 
Rajappa S. Tetrahedron. 1995; 51:10571.(j) Forzato C, Nitti P, Pitacco G, Valentin E, Morganti S, Rizzato E, Spinelli D, Dell'Erba C, Petrillo G, Tavani C. Tetrahedron. 2004; 60:11011.

64. Dong L, Miller MJ. J. Org. Chem. 2002; 67:4759. [PubMed: 12098286]

65. Still WC, Kahn M, Mitra A. J. Org. Chem. 1978; 43:2923.

66. Loudon GM, Radhakrishna AS, Almond MR, Blodgett JK, Boutin RH. J. Org. Chem. 1984; 49:4272. 
<smiles>CCC(=O)N[C@@H](C[C@@H]1CC[C@@](C(=O)O)([C@H](O)[C@@H](N)C(=O)O)N1)C(=O)O</smiles><smiles>C[C@]12OC(=O)[C@]1([C@H](O)C1=CCCCC1)NC(=O)[C@@H]2CCCl</smiles>

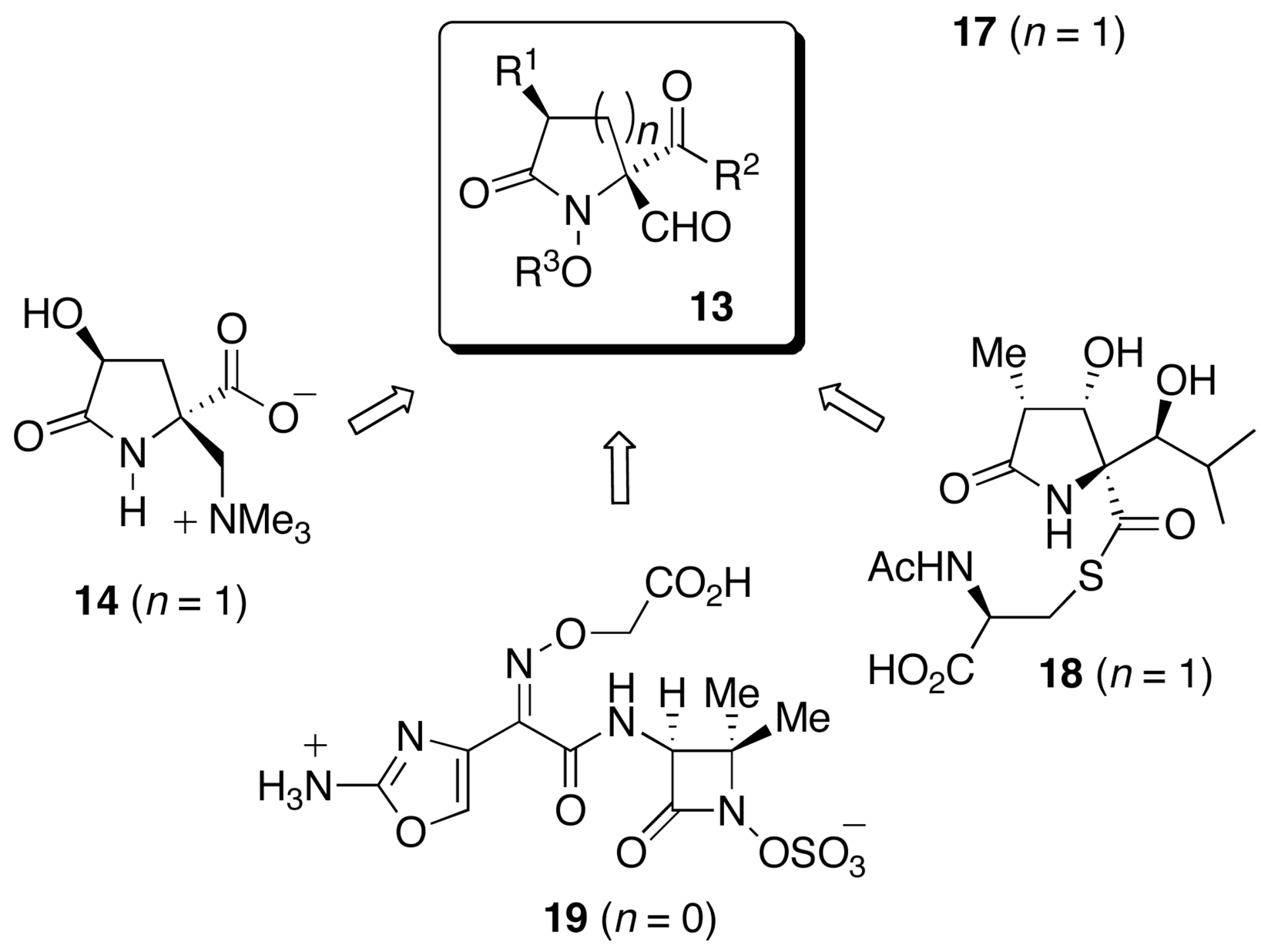

Figure 1.

Synthetic targets potentially accessible via nitrenium ion cyclization-dienone cleavage strategy. 


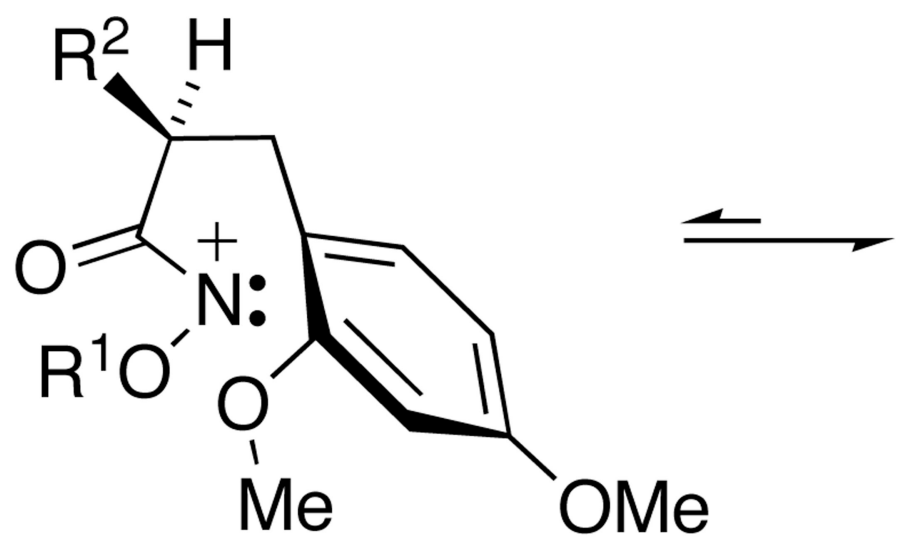

A (disfavored)

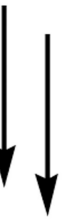

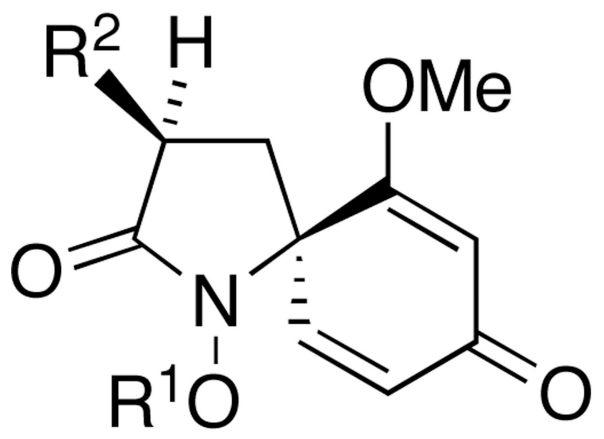

syn-12

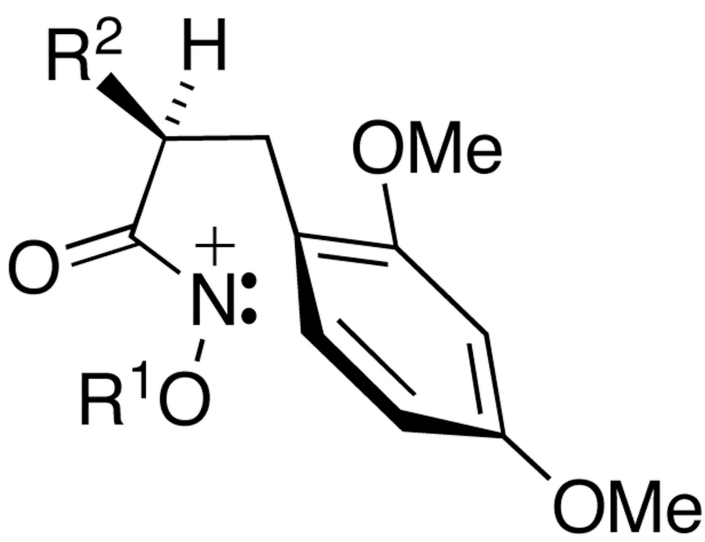

B (favored)
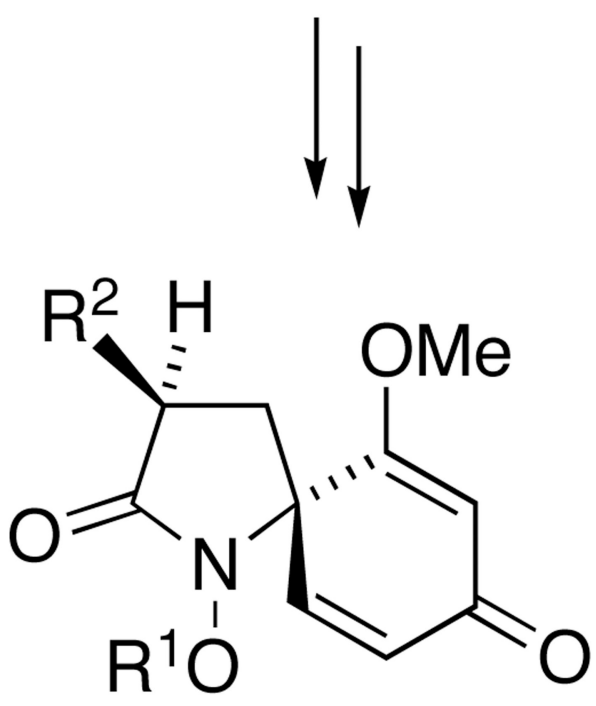

anti-12

Figure 2.

Benzylic strain in the putative nitrenium ion intermediate leads to selective formation of anti-12. 


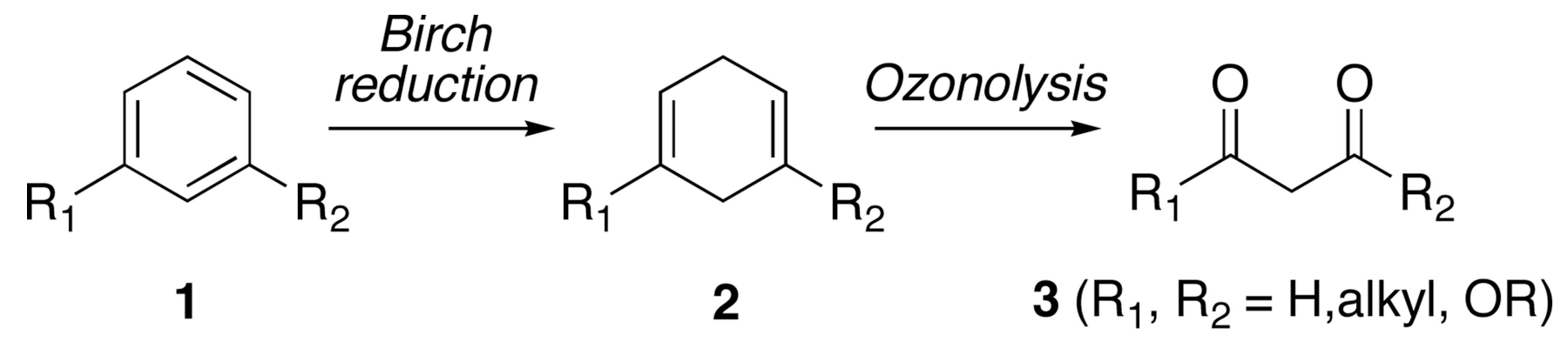

Scheme 1.

1,3-Disubstituted Arenes as Masked $\beta$-Oxo Carbonyl Synthons 


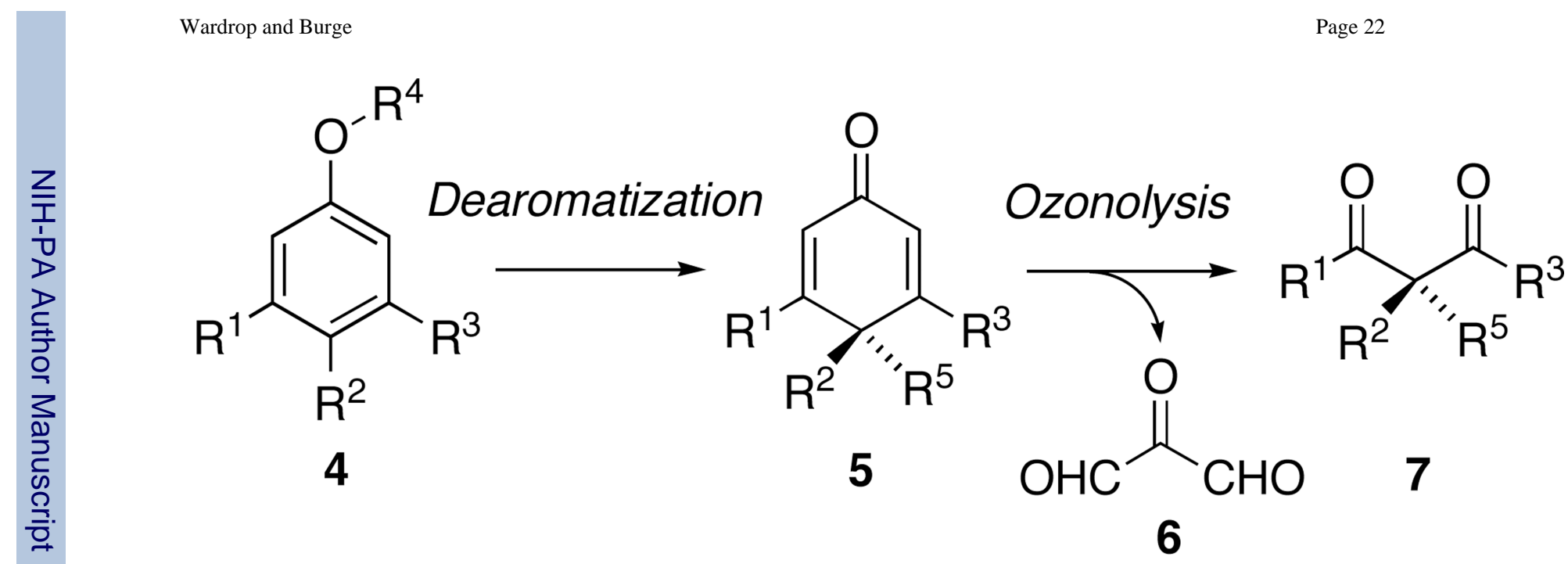

Scheme 2.

2,5-Cyclohexadienones as Potential Masked $\beta$-Oxo Carbonyl Synthons 


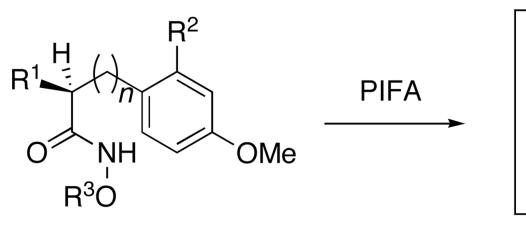

10

$\mathrm{PIFA}=\mathrm{Phl}\left(\mathrm{OCOCF}_{3}\right)_{2}$

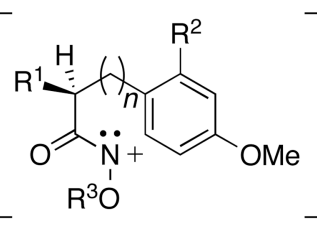

11

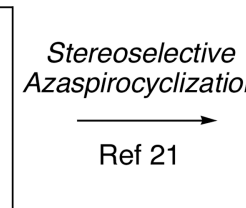

Stereoselective

Ref 21

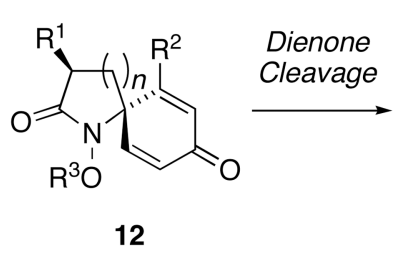

12

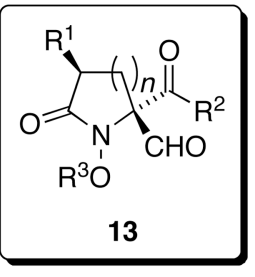

Scheme 3.

Spirocyclic Lactams as Masked Heterocyclic $\beta$-Oxo Carbonyl Synthons 

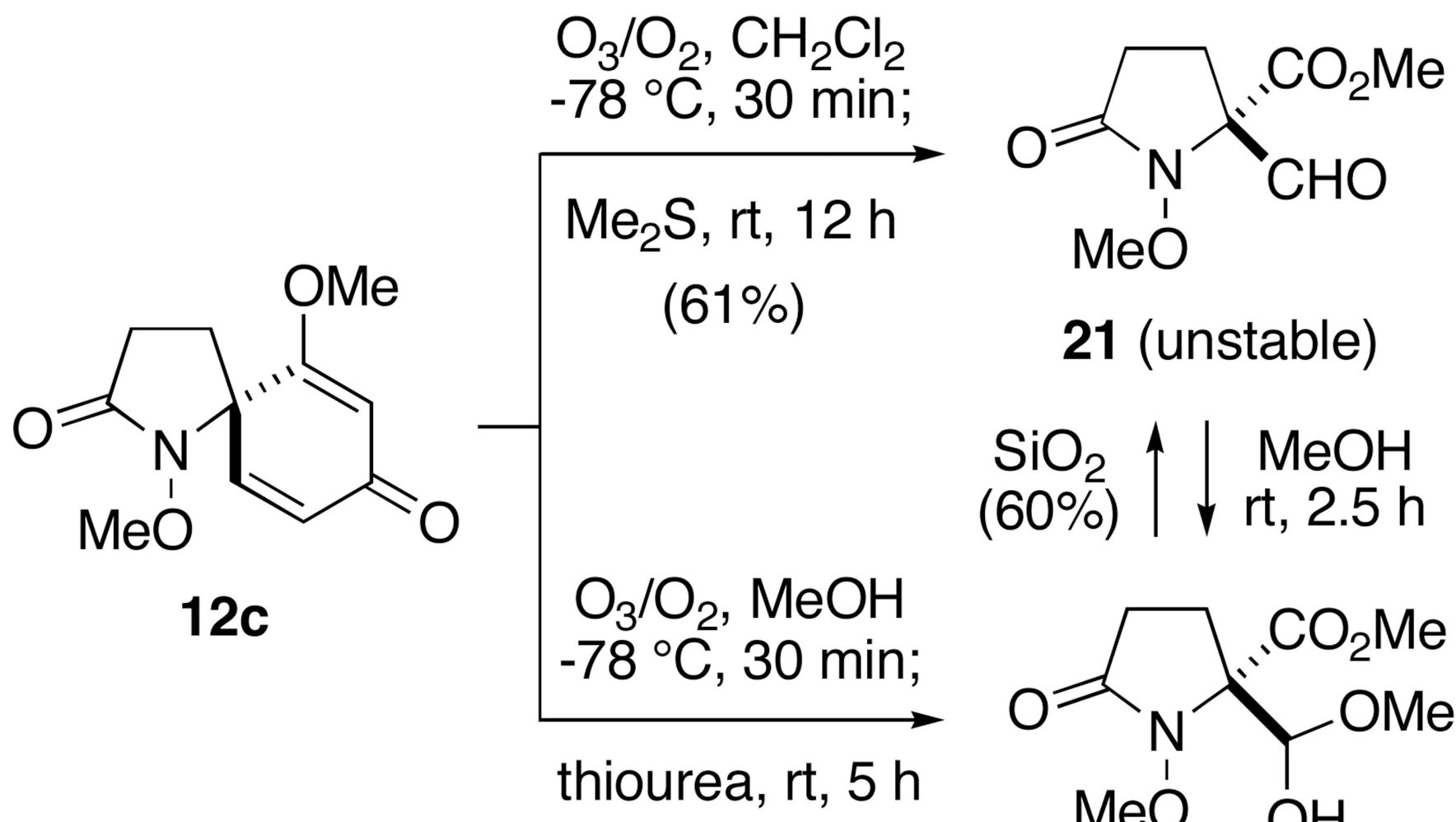

21 (unstable)

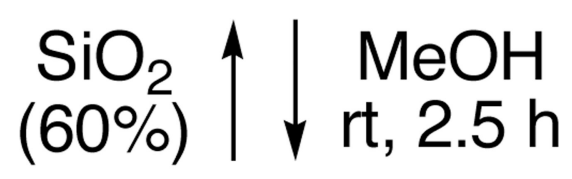

Scheme 4.

Exploratory Dienone Ozonolysis Studies

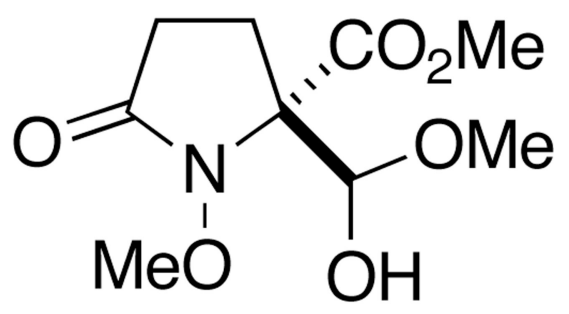

22 (unstable) 


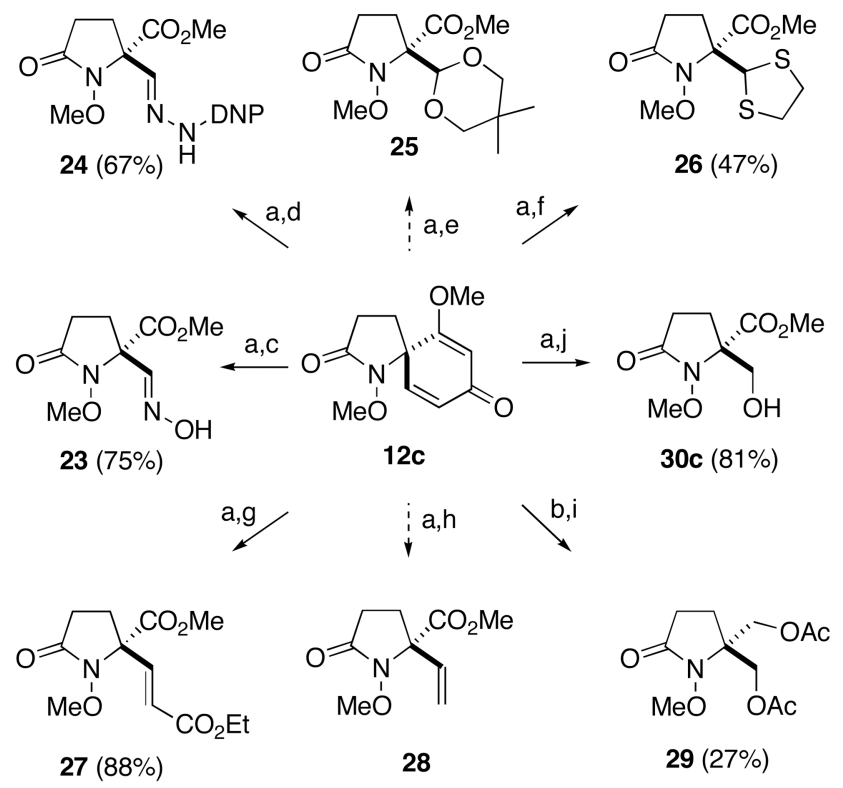

${ }^{a}$ Reagents and conditions: (a) $\mathrm{O}_{3} / \mathrm{O}_{2}, \mathrm{MeOH},-78{ }^{\circ} \mathrm{C}, 30 \mathrm{~min}$; thiourea, $-78{ }^{\circ} \mathrm{C} \rightarrow \mathrm{rt}, 30 \mathrm{~min}$; (b) $\mathrm{O}_{3} / \mathrm{O}_{2}$, $\mathrm{CH}_{2} \mathrm{Cl}_{2},-78{ }^{\circ} \mathrm{C}, 30 \mathrm{~min} ; \mathrm{Me}_{2} \mathrm{~S},-78{ }^{\circ} \mathrm{C} \rightarrow \mathrm{rt}, 4 \mathrm{~h}$; (c) $\mathrm{H}_{2} \mathrm{NOH} \bullet \mathrm{HCl}, \mathrm{NaOAc}, \mathrm{MeOH}, \mathrm{rt}, 3 \mathrm{~h}(75 \%$ ); (d) 2,4$\mathrm{DNPH}, \mathrm{HCl}$ (conc), $\mathrm{MeOH}, 3 \AA \mathrm{ms}$, reflux, $3 \mathrm{~h}(67 \%)$; (e) $\mathrm{Me}_{2} \mathrm{C}\left(\mathrm{CH}_{2} \mathrm{OH}\right)_{2}$, TsOH, $3 \AA$ m.s., $\mathrm{CH}_{2} \mathrm{Cl}_{2}$, reflux, $16 \mathrm{~h}$ (decomposition); (f) $\left(\mathrm{CH}_{2} \mathrm{SH}\right)_{2}, \mathrm{HCl}$ (conc), rt, $16 \mathrm{~h}(47 \%)$; (g) $\mathrm{Ph}_{3} \mathrm{P}=\mathrm{CHCO}_{2} \mathrm{Et}, \mathrm{PhCH}_{3}$, reflux, $2 \mathrm{~h}(88 \%)$; (h) $\mathrm{Ph}_{3} \mathrm{P}=\mathrm{CH}_{2}, \mathrm{THF}, \mathrm{rt}, 14 \mathrm{~h}$ (decomposition); (i) $\mathrm{LiBH}_{4}$, THF, rt, 16 h then $\mathrm{Ac}_{2} \mathrm{O}$, py, rt 24 h (27\%); (j) $\mathrm{NaBH}(\mathrm{OAc})_{3}, \mathrm{AcOH}, \mathrm{rt}, 20 \mathrm{~h}(81 \%)$.

\section{Scheme 5.}

One-Pot Dienone Ozonolysis and Trapping a

${ }^{a}$ Reagents and conditions: (a) $\mathrm{O}_{3} / \mathrm{O}_{2}, \mathrm{MeOH},-78{ }^{\circ} \mathrm{C}, 30 \mathrm{~min}$; thiourea, $-78{ }^{\circ} \mathrm{C} \rightarrow \mathrm{rt}, 30$ min; (b) $\mathrm{O}_{3} / \mathrm{O}_{2}, \mathrm{CH}_{2} \mathrm{Cl}_{2},-78^{\circ} \mathrm{C}, 30 \mathrm{~min} ; \mathrm{Me}_{2} \mathrm{~S},-78^{\circ} \mathrm{C} \rightarrow \mathrm{rt}, 4 \mathrm{~h}$; (c) $\mathrm{H}_{2} \mathrm{NOH} \cdot \mathrm{HCl}, \mathrm{NaOAc}$, $\mathrm{MeOH}, \mathrm{rt}, 3 \mathrm{~h}$ (75\%); (d) 2,4-DNPH, HCl (conc), MeOH, $3 \AA$ ms, reflux, 3 h (67\%); (e) $\mathrm{Me}_{2} \mathrm{C}\left(\mathrm{CH}_{2} \mathrm{OH}\right)_{2}$, TsOH, $3 \AA$ m.s., $\mathrm{CH}_{2} \mathrm{Cl}_{2}$, reflux, $16 \mathrm{~h}$ (decomposition); (f) $\left(\mathrm{CH}_{2} \mathrm{SH}\right)_{2}, \mathrm{HCl}$ (conc), rt, 16 h (47\%); (g) $\mathrm{Ph}_{3} \mathrm{P}=\mathrm{CHCO}_{2} \mathrm{Et}, \mathrm{PhCH}_{3}$, reflux, 2 h $\left(88 \%\right.$ ); (h) $\mathrm{Ph}_{3} \mathrm{P}=\mathrm{CH}_{2}, \mathrm{THF}$, rt, $14 \mathrm{~h}$ (decomposition); (i) $\mathrm{LiBH}_{4}, \mathrm{THF}, \mathrm{rt}, 16 \mathrm{~h}$ then $\mathrm{Ac}_{2} \mathrm{O}$, py, rt $24 \mathrm{~h} \mathrm{(27 \% );} \mathrm{(j)}$ $\mathrm{NaBH}(\mathrm{OAc})_{3}, \mathrm{AcOH}, \mathrm{rt}, 20 \mathrm{~h}(81 \%)$. 
<smiles>COC1=CC(=O)C=C[C@]12CCC(=O)N2OC</smiles>

$12 c$

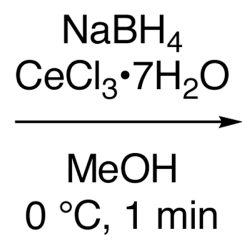

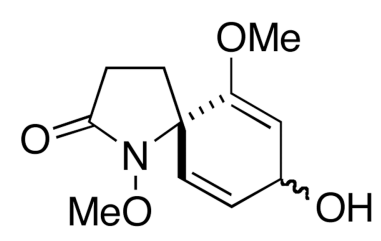

31 (unstable)
$\mathrm{O}_{3} / \mathrm{O}_{2}, \mathrm{MeOH}$ $-78^{\circ} \mathrm{C}, 30 \mathrm{~min}$; thiourea, $1 \mathrm{~h}$;

$\mathrm{NaBH}(\mathrm{OAc})_{3}$ $\mathrm{AcOH}, \mathrm{rt}, 24 \mathrm{~h}$

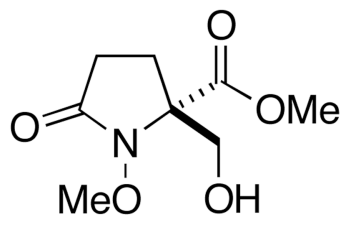

30c $(76 \%$ overall)

Scheme 6.

Alternative, Two-Step Protocol for the Cleavage of Spirodienone Lactams 12. 


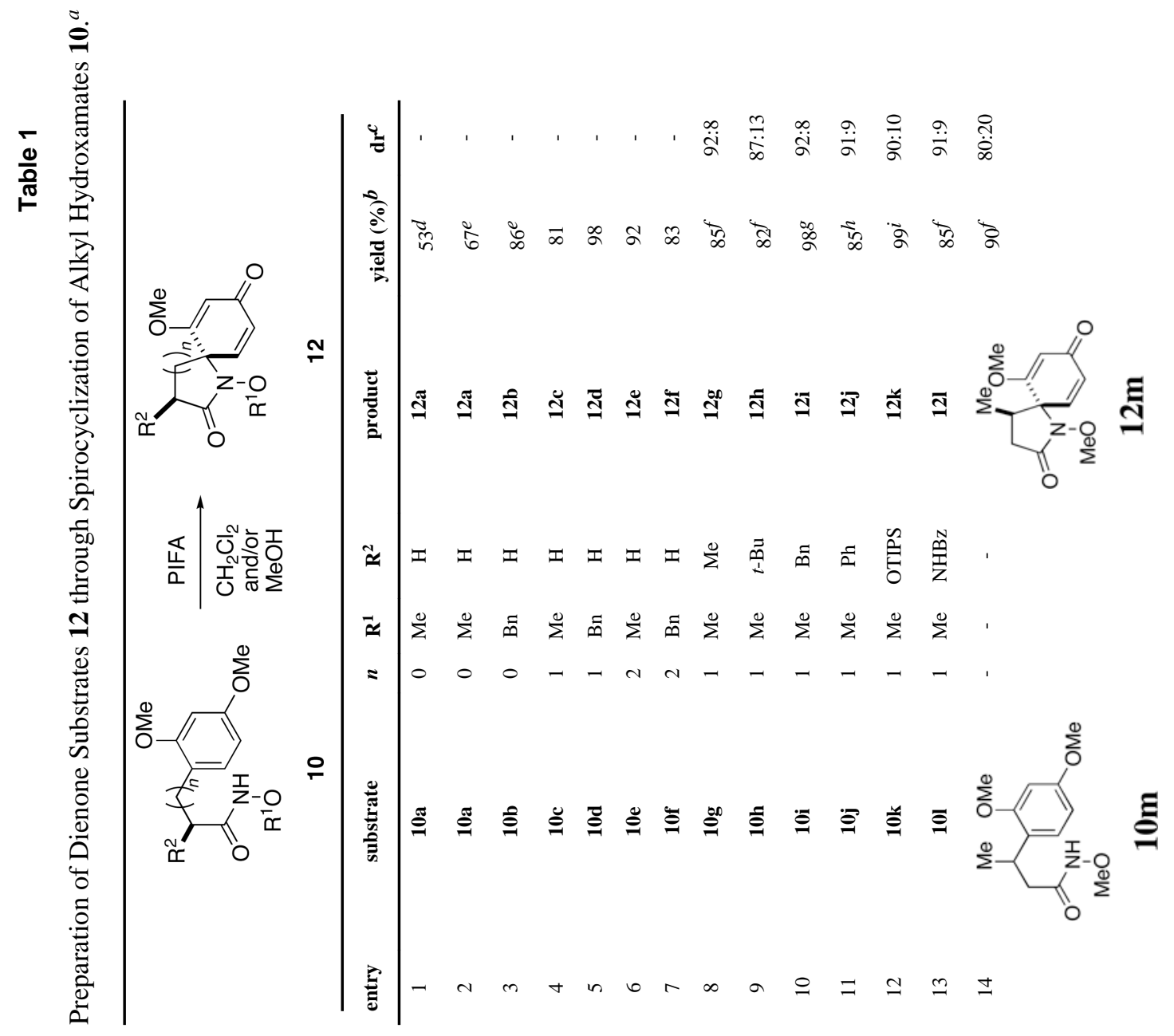

J Org Chem. Author manuscript; available in PMC 2012 March 20. 


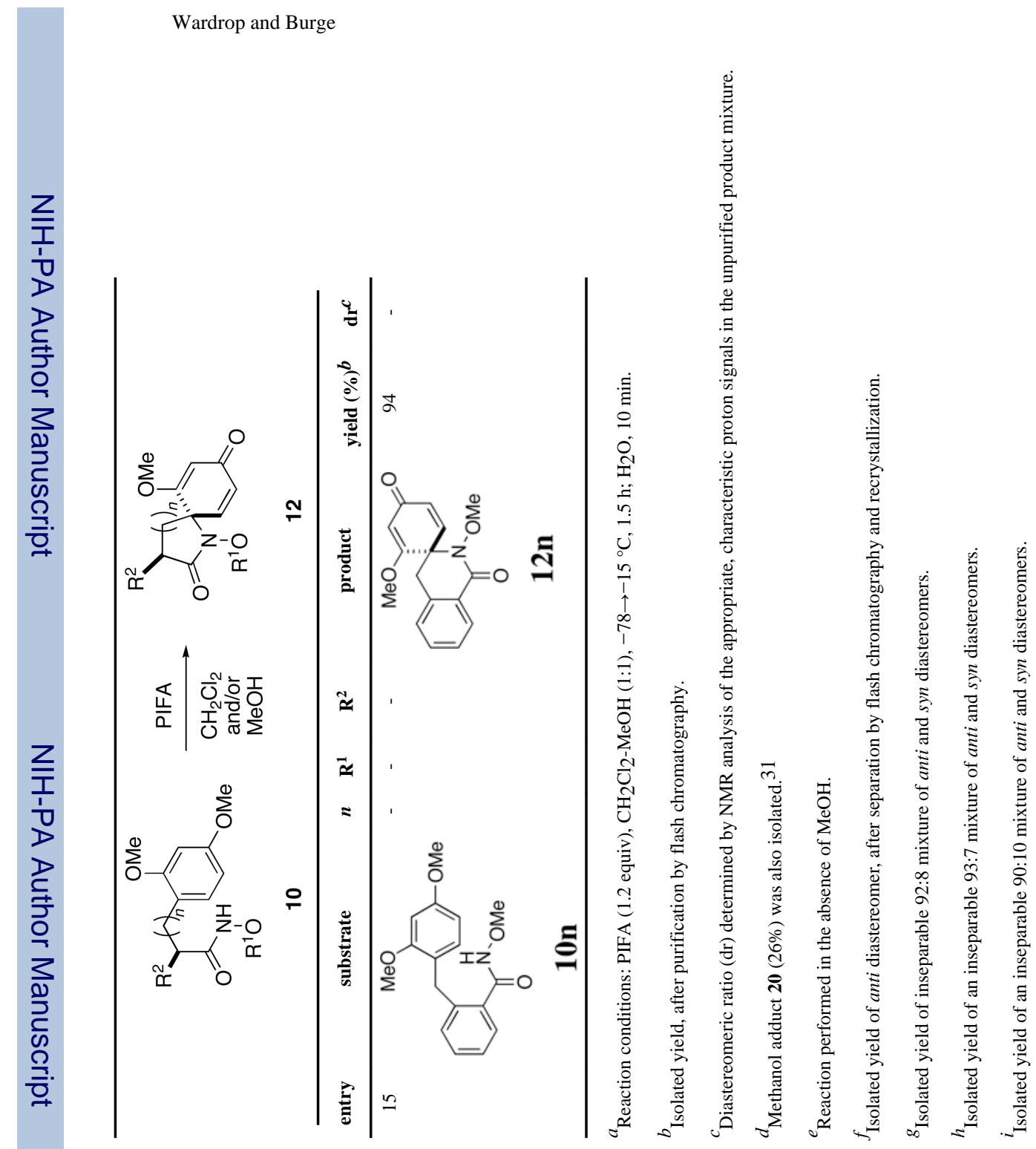

Page 28 


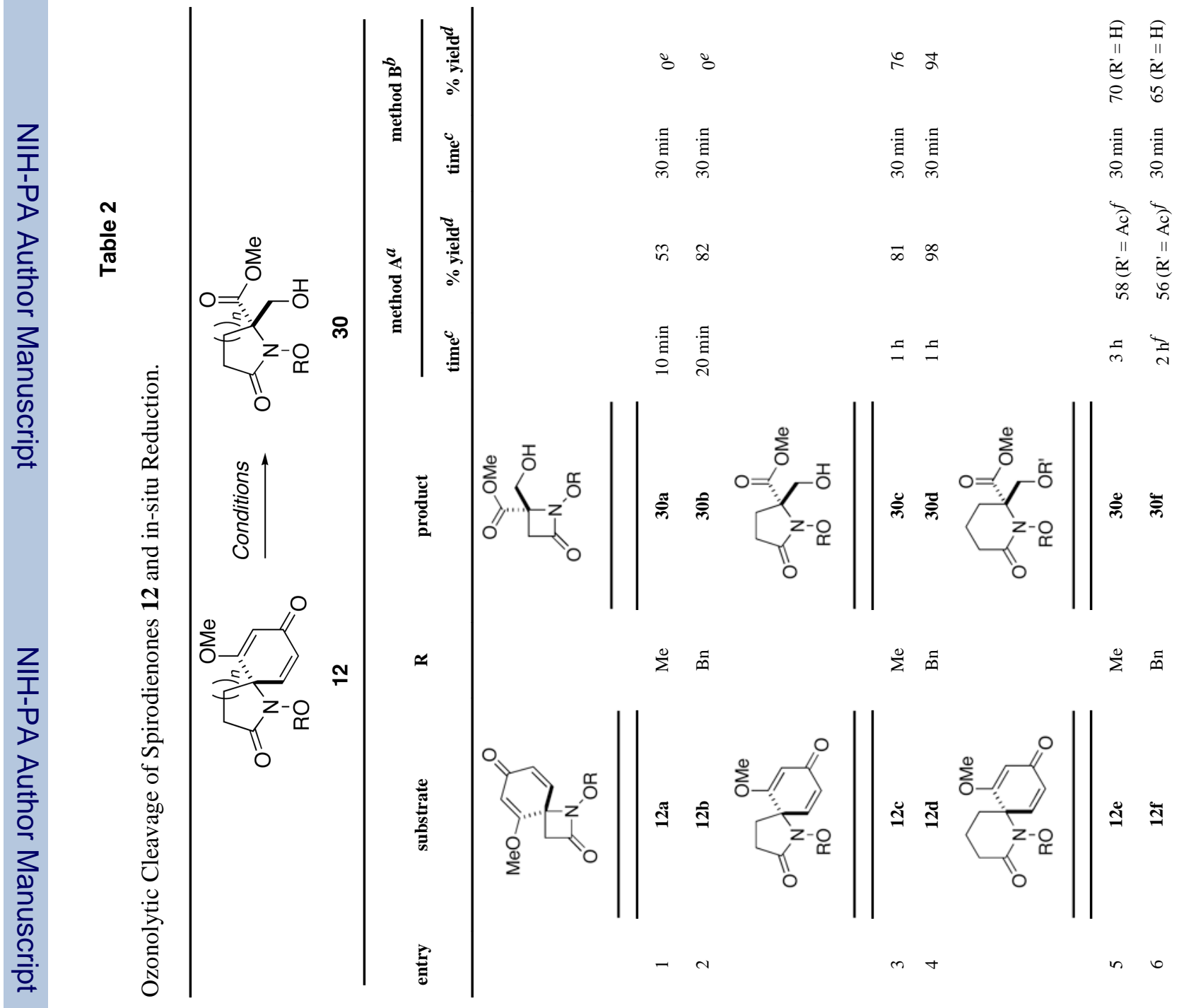




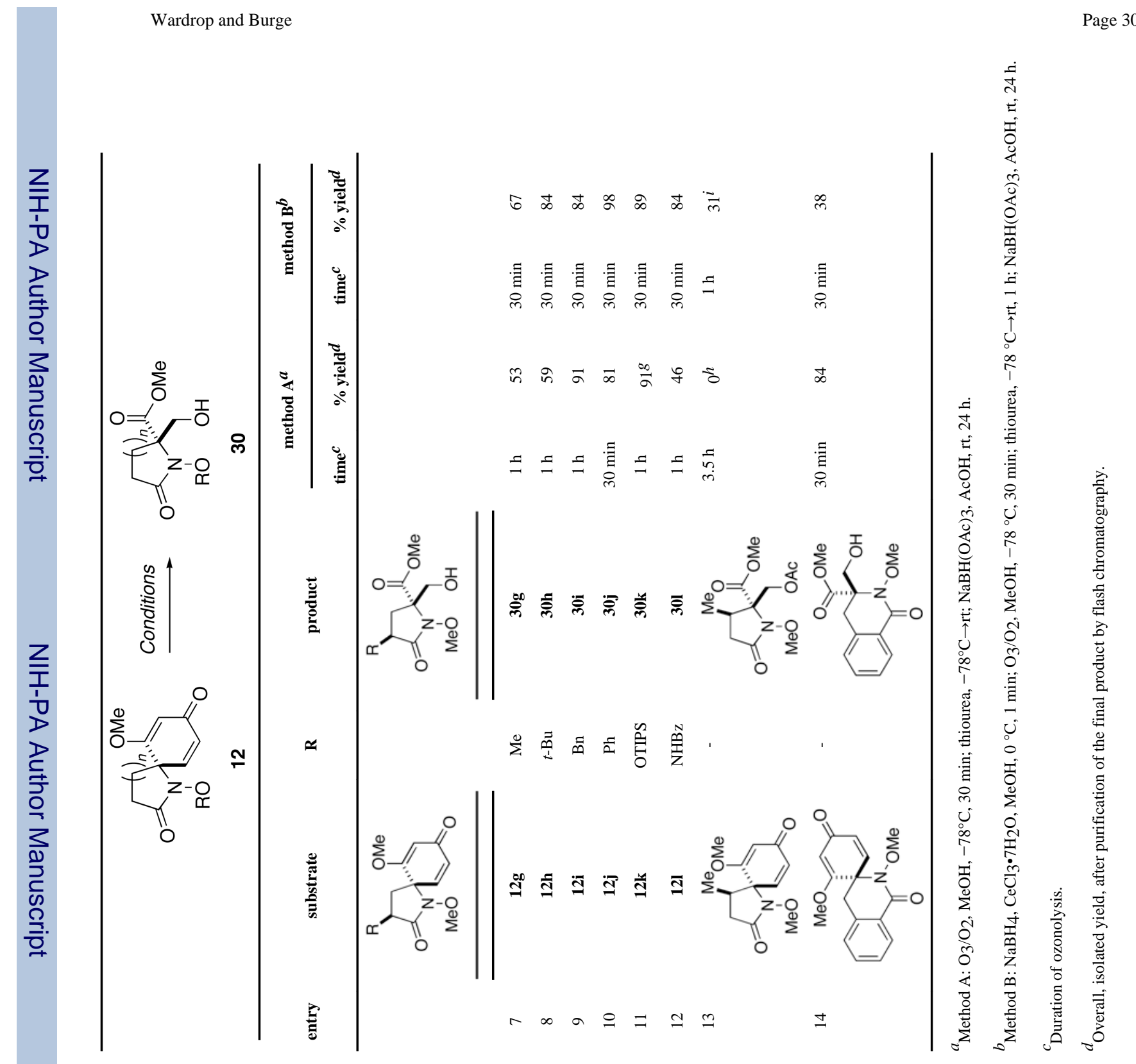

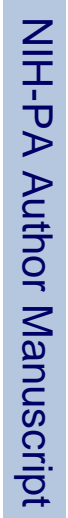




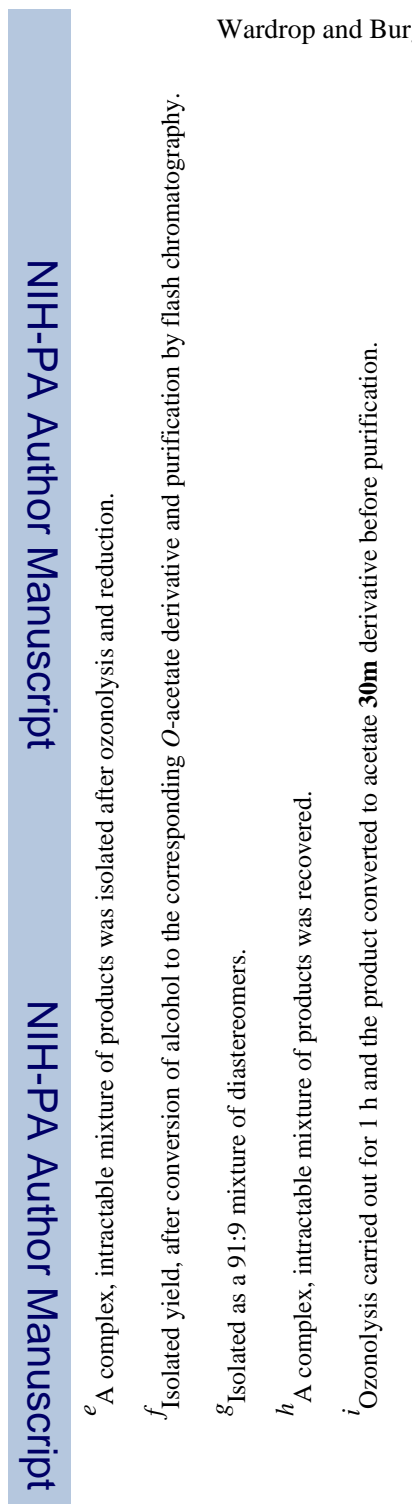

J Org Chem. Author manuscript; available in PMC 2012 March 20. 
Table 3

Relationship between Spirodienone Reactivity and Structure.

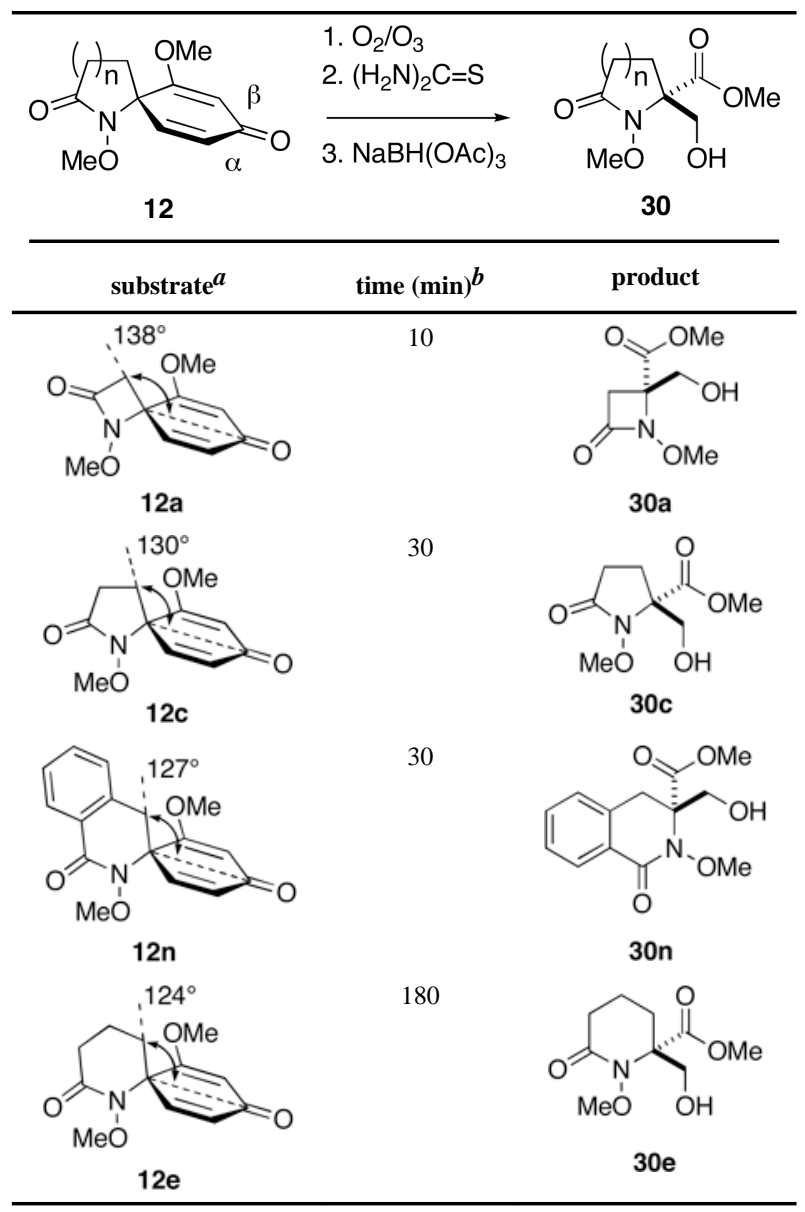

${ }^{a}$ Optimized geometries were obtained through the MMMF force field implemented in Spartan.

${ }^{b}$ Duration of ozonolysis. 


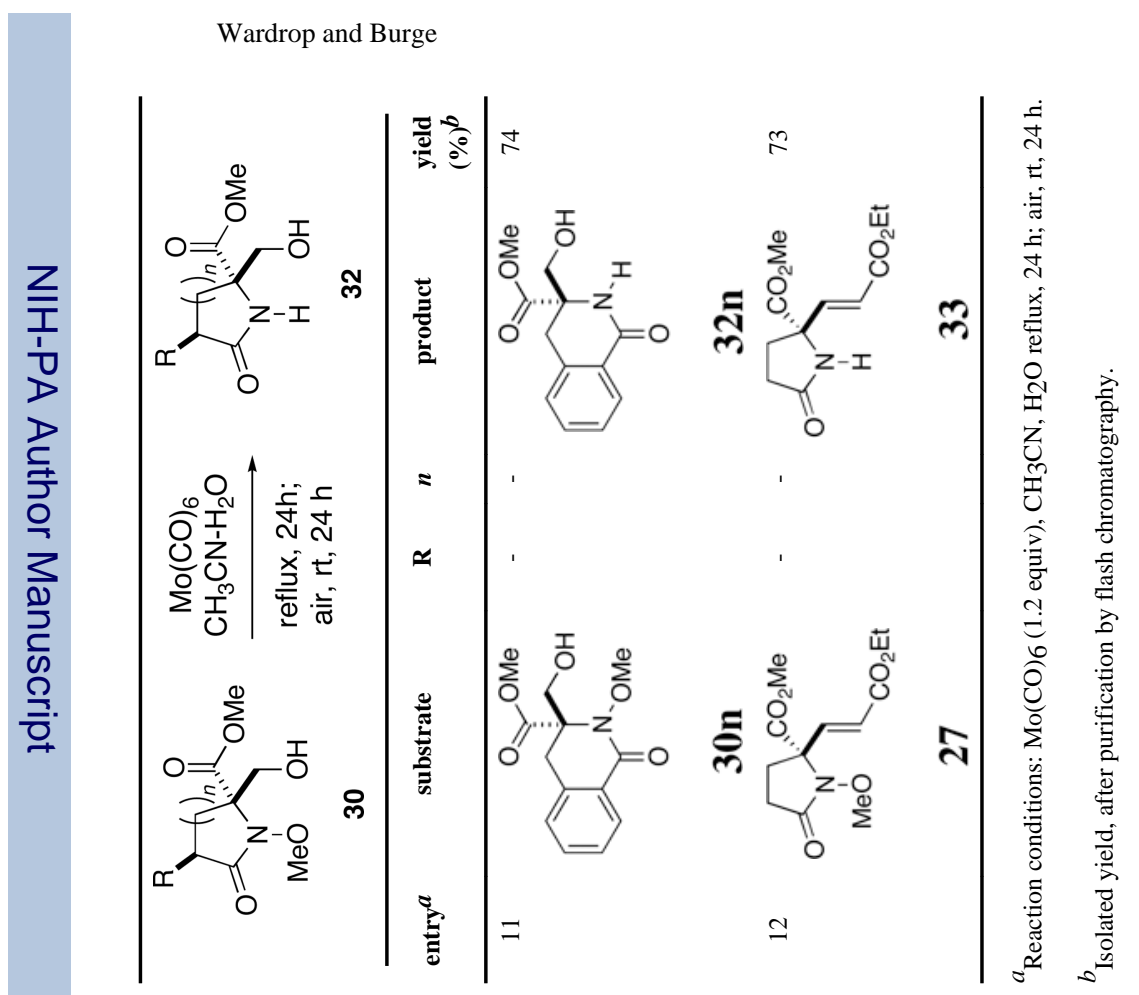

Page 34 
